\title{
The chemistry of quartz in granitic pegmatites of southern Norway: petrogenetic and economic implications
}

Axel Müller ${ }^{1,2}$, Peter M. Ihlen ${ }^{3}$, Ben Snook ${ }^{3}$, Rune Larsen ${ }^{4}$, Belinda Flem³ ${ }^{3}$ Bernard Bingen ${ }^{3}$, Ben J. Williamson ${ }^{5}$

${ }^{1}$ Natural History Museum, University of Oslo, P.O. Box 1172, Blindern, 0318 Oslo, Norway, e-mail: axel.muller@nhm.uio.no

${ }^{2}$ Natural History Museum, Cromwell Road, London SW7 5BD, UK

${ }^{3}$ Geological Survey of Norway, P.O. Box 6315 Sluppen, N-7491 Trondheim, Norway

${ }^{4}$ Norwegian University of Science and Technology, N-7491 Trondheim, Norway

${ }^{5}$ Camborne School of Mines, University of Exeter, Cornwall Campus, Penryn TR10 9EZ,

UK 


\begin{abstract}
Trace element concentrations in quartz from 188 granitic pegmatites in the Froland and EvjeIveland pegmatite fields, southern Norway, have been determined to establish exploration targets for high-purity quartz (HPQ) and to gain a better understanding of the genesis of pegmatites hosting HPQ deposits. Both pegmatite fields were formed during the Sveconorwegian (Grenvillian) orogeny (1145 to $900 \mathrm{Ma}$ ) at the western margin of the Fennoscandian Shield.

In situ raster analyses within single quartz crystals were undertaken by laser ablation inductively coupled plasma mass spectrometry (spot size $75 \mu \mathrm{m}$ ) to assess levels of latticebound impurities, rather than mineral and fluid inclusions which are relatively easily removed during HPQ processing. Quartz in the Froland pegmatites has relatively pure and homogeneous compositions containing $46 \pm 24 \mu \mathrm{gg}^{-1} \mathrm{Al}, 8 \pm 3 \mu \mathrm{gg}^{-1} \mathrm{Ti}, 1.4 \pm 0.8 \mu \mathrm{gg}^{-1} \mathrm{Ge}$, and $11 \pm 7 \mu \mathrm{gg}^{-1} \mathrm{Li}$. The Ti-in-quartz geothermobarometer gives an average pegmatite crystallisation temperature of $537 \pm 39^{\circ} \mathrm{C}$. Temperatures estimates are highest along the NW margin of the pegmatite field $\left(>550^{\circ} \mathrm{C}\right)$, whereas the most differentiated pegmatites occur towards the NE. The area of greatest economic potential for HPQ lies just north of the central part of the field where individual pegmatites contain $>1$ Mt quartz with low average trace element contents of $67 \pm 11{\mu g g^{-1}}^{1}$. From mineral-chemical criteria, and a range of other geological factors, we propose that pegmatite melts in the Froland field were generated by fluid-present crustal melting at about $1060 \mathrm{Ma}$, in zones of localized high-strain deformation during progressive thrusting along the Porsgrunn-Kristiansand Fault Zone (PKFZ).

Quartz in the Evje-Iveland pegmatites has more variable compositions with $69 \pm 57 \mu \mathrm{gg}^{-}$ ${ }^{1} \mathrm{Al}, 19 \pm 11 \mu \mathrm{gg}^{-1} \mathrm{Ti}, 2.3 \pm 1.8 \mu \mathrm{gg}^{-1} \mathrm{Ge}$, and $7 \pm 5 \mu \mathrm{gg}^{-1} \mathrm{Li}$. From its Ti content, it crystallised at temperatures of $613 \pm 70^{\circ} \mathrm{C}$. The regional spatial distribution of Ti-in-quartz temperatures appears irregular mainly due to the scattered distributions of chemical evolved pegmatites with "amazonite"-"cleavelandite" replacement zones which show crystallization temperatures down to $442{ }^{\circ} \mathrm{C}$. Quartz from the Evje-Iveland pegmatites is unlikely to be of current economic interest due to its moderate to high trace element contents, heterogeneous chemistry and low volume. The Evje-Iveland pegmatites show no apparent genetic link to a granite intrusion. Instead they probably formed as a result of partial melting at depth of their amphibolite country rocks at around $910 \mathrm{Ma}$. This is related to a regional low-pressure/hightemperature metamorphic event at about 930-920 Ma.
\end{abstract}

\title{
Keywords
}

High-purity quartz, pegmatite, LA-ICP-MS, Evje-Iveland, Froland 


\section{Introduction}

The trace element chemistry of quartz is of crucial importance in defining the characteristics and geological environments of high-purity quartz (HPQ) deposits. Naturally occurring HPQ, defined as containing less than $50 \mu \mathrm{gg}^{-1}$ trace elements (Harben, 2002), is of increasing demand due to emerging applications in the production of high-tech components such as optical fibres, halogen lamps, silica glass crucibles, computer chips and solar panels, making this rare material an economically and strategically important resource (Haus, 2005). Ensuring future supply of HPQ necessitates the development of exploration tools for rapid deposit identification, which itself requires a better understanding of the regional and local environments of its formation. Currently, HPQ is mainly sourced from granites and largevolume $\left(>100,000 \mathrm{~m}^{3}\right)$ pegmatites and less commonly from hydrothermal veins and quartzites (e.g., Müller et al., 2012b). The advantage of pegmatite deposits is the large size of quartz crystals, allowing them to be easily separated from other pegmatite-forming minerals.

Impurities in quartz are the main controls on HPQ quality as they can only be partly removed during processing (Haus et al., 2012). These impurities include: (i) lattice-bound trace elements, (ii) sub-micron inclusions, and (iii) mineral and fluid inclusions $(>1 \mu \mathrm{m}$ in size) (Weil, 1993; Van den Kerkhof and Hein, 2001; Götze et al., 2004; Stevens-Kalceff, 2009; Seifert et al., 2011). Lattice-bound trace elements are the most problematic, as they cannot currently be removed or reduced by processing. Assessing their often very low concentrations is best achieved using a spatially-resolved and high sensitivity technique such as laser ablation inductively coupled plasma mass spectrometry (LA-ICP-MS).

In previous studies, chemical composition of feldspars, micas and other pegmatiteforming minerals were utilized to illustrate pegmatite-internal and regional zonation and fractionation trends (Černy et al., 1985; Smeds, 1992; Černy, 1994; Neiva, 1995). However, comparatively little of this type of work has been carried out on the chemistry of pegmatite quartz. The limited number of publications is in contrast to the abundant studies dealing with trace elements of hydrothermal (e.g., Rusk et al. 2006, 2008, 2011; Rusk, 2012, 2014; Tanner et al., 2013; Maydagán et al., 2015), volcanic (e.g., Watt et al., 1997; Wark et al., 2007; Audétat, 2013), plutonic (e.g., Müller et al., 2000; Wiebe et al., 2007; Jacamon and Larsen, 2009; Müller et al., 2010b; Breiter et al., 2013), metamorphic (e.g., Van den Kerkhof et al., 2004; Spear and Wark, 2009; Kidder et al., 2013), and sedimentary quartz (e.g., Götze and Plötze, 1997; Götze, 2012; Götte et al., 2013; Müller and Knies, 2013).

Similar to other pegmatite-forming minerals, quartz preserves crystal-chemical signatures which reflect conditions during pegmatite crystallization and can be used for petrogenetic interpretations. This in turn helps to better understand the formation conditions of igneous HPQ. Schrön et al. (1988) were the presumably the first who distinguished pegmatite quartz from volcanic and plutonic quartz by its $\mathrm{Ge}$, Ti and $\mathrm{Al}$ content. More recent studies of pegmatite quartz (Larsen et al., 2000b, 2004; Götze et al., 2004, 2005; Müller et al., 2008a; Breiter and Müller, 2009; Beurlen et al., 2011) largely take advantage of the development of micro-beam techniques enabling the precise in situ determination of latticebound trace elements. These have shown that quartz trace element contents are variable within different pegmatite bodies, locally, between pegmatites of the same origin, and regionally, amongst pegmatites of different origin. Quartz chemistry is affected by the composition of the pegmatite magma and pressure and temperature conditions during quartz crystallisation. Ti concentrations in quartz have been shown to be a function of crystallisation temperature and pressure (e.g., Wark and Watson, 2006; Thomas et al., 2010; Huang and Audétat, 2012). Concentrations of $\mathrm{Al}, \mathrm{Li}$, and $\mathrm{Ge}$ in igneous and pegmatite quartz reflect, at least partially, the abundance of these elements in the granitic and pegmatitic melts and, thus, 
the degree of chemical differentiation (e.g., Breiter and Müller, 2009; Jacamon and Larsen, 2009; Müller et al., 2010b; Breiter et al., 2013; Beurlen et al., 2011).

In this study, lattice-bound trace element concentrations in quartz from granitic pegmatites of the Froland and Evje-Iveland pegmatite fields in south Norway were investigated using LA-ICP-MS. The two pegmatite fields are part of the Sveconorwegian pegmatite province. The data represented in this paper are a compilation of results from several projects conducted by the Geological Survey of Norway in the period between 1999 and 2013; partly in collaboration with industry partners. The objectives of these projects were to develop routine methods for the determination of ultra-trace element concentrations in quartz by LA-ICP-MS (Larsen et al., 2000a; Flem et al., 2002; Müller et al., 2008b; Flem and Müller, 2012), to characterise and define different types of HPQ deposits, to explore both regionally and locally the distribution of HPQ deposits and to increase our knowledge about their formation (Larsen, 1999; Larsen et al., 2000b; Ihlen et al., 2001, 2002; Müller et al., 2008a).

The aims of the current study are: (1) to determine the lattice-bound trace element contents and thus the chemical quality of pegmatitic quartz from the Froland and EvjeIveland pegmatite fields; (2) to document possible intra-pegmatite chemical zonation of trace elements in quartz; (3) to establish the nature and causes of regional (km-scale) distribution patterns of trace element contents of quartz within each pegmatite field; 4) to compare quartz chemistry between the two pegmatite fields to identify and study the causes of these intrafield differences; and (5) to identify target areas for HPQ exploration. The current economic potential of the investigated pegmatites is evaluated. Regional trace element distributions in quartz have been studied to establish the magmatic differentiation and temperature gradients within both pegmatite fields in order to test if these gradients may help to localise HPQ occurrences. The results provide information about the tectonometamorphic setting at the time of pegmatite emplacement and the origin of the pegmatite melts, and baseline criteria for exploring for further HPQ deposits in similar such pegmatite fields worldwide.

\section{Geological background}

The Froland and Evje-Iveland granitic pegmatite fields lie within the Sveconorwegian pegmatite province which covers most of south Norway (Fig. 1). These two fields formed during the Sveconorwegian (Grenvillian) orogeny (1145 to $900 \mathrm{Ma}$ ) at the southwestern margin of the Fennoscandian shield. The Froland field forms part of the Bamble pegmatite district within the Bamble lithotectonic domain, which is exposed along the coast of Skagerrak. The Evje-Iveland field is part of the Setesdalen pegmatite district in the Telemark lithotectonic domain (Andersen et al., 2004). These two lithotectonic units are separated by the Porsgrunn-Kristiansand Fault Zone (PKFZ), which is a ca. $150 \mathrm{~km}$ long NE-trending, polyphase shear zone, that formed in response to NW-directed thrusting of the Bamble on top of the Telemark domain (Fig. 2). This thrusting was followed by normal faulting and shearing which resulted in the down-throw of the Bamble domain (Starmer, 1993; Henderson and Ihlen, 2004; Mulch et al., 2005). The Bamble domain, in the hangingwall of the PKFZ hosting the Froland pegmatite field, is characterized by an early Sveconorwegian tectonometamorphic history (1145-1080 Ma), whilst the Telemark lithotectonic domain, in the footwall of the PKFZ, which hosts the Evje-Iveland pegmatite field, was exhumed and cooled much later in the orogeny (930-900 Ma) (Kullerud and Dahlgren, 1993; Cosca et al., 1998; Bingen et al., 1998; Bingen et al., 2008b). The two pegmatite fields therefore differ in age, tectonometamorphic setting and rare mineral parageneses. 


\subsection{Froland pegmatites}

The Froland pegmatite field comprises more than 105 large $\left(>1000 \mathrm{~m}^{3}\right)$ pegmatite bodies. These pegmatites were quarried in the past for feldspar within a NNE-SSW-trending area measuring $20 \mathrm{~km}$ by $5 \mathrm{~km}$. The pegmatite field, which lies above the SE-dipping basal thrust of the PKFZ, is oriented roughly parallel to the regional structural grain in the Bamble domain and the PKFZ (Fig. 3).

The poly-generation Froland field is subdivided into syn-orogenic (1145 to $1060 \mathrm{Ma}$ ), late-orogenic $(926 \pm 8 \mathrm{Ma}$; emplacement age of the nearby Herefoss pluton and Holtebu granite) and post-orogenic pegmatites $(<926 \pm 8 \mathrm{Ma}$; Ihlen et al., 2002). In this study, only the syn-orogenic pegmatites, which constitute more than $95 \%$ of the bodies in the field, are considered. The intrusion age of the syn-orogenic pegmatites is uncertain. However, it is likely to be similar to the Gloserhei pegmatite, situated some $15 \mathrm{~km}$ E of the Froland field, which is considered to be of the same genetic and chemical type as the Froland pegmatites (Åmli, 1977). This produced a U/Pb upper-intercept age for euxenite of $1060+8 /-6 \mathrm{Ma}$ (Baadsgaard et al., 1984).

The syn-orogenic Froland pegmatites are significantly older than nearby exposed granite plutons, namely the Herefoss pluton and the Holtebu granite, both dated at $926 \pm 8 \mathrm{Ma}$ (Andersen, 1997), which is supported by field observations. However, the existence of a hidden granite pluton of the same age below the pegmatite field cannot be entirely excluded, although it is very unlikely given the nature of the regional Bouguer anomaly field (Gellein, 2003) and magnetic residual field (Sindre, 1992). The gravity field of the area where the Froland pegmatites emplaced is dominated by high density rocks down to at least $5 \mathrm{~km}$ depth forming a positive gravity anomaly. The adjacent Herefoss intrusion forms a strong negative anomaly caused by the low density of granitic rocks.

According to the classification of Černý and Ercit (2005), the syn-orogenic Froland pegmatites comprise simple abyssal, primitive rare-element REE and muscovite rare-element REE pegmatites. The mineralogy, mineral chemistry, structures and genesis of the pegmatites have been studied by Andersen (1926, 1931), Bjørlykke (1937), Ihlen et al. (2001, 2002), Larsen (2002), Larsen et al. (2004), Henderson and Ihlen (2004) and Müller et al. (2005, 2008a). They have variable contents of quartz, alkali feldspar, plagioclase, biotite, and subordinate white mica (Ihlen et al., 2001, 2002). Although the pegmatites are generally very low in garnet and accessory Y-REE-Nb-Th minerals, some groups of pegmatites show enhanced contents of Niobium-Yttrium-Fluorine(NYF)-type rare mineral assemblages including e.g. euxenite, samarskite, aeschynite, fergusonite, allanite, beryl, thorite, and uraninite. About 60 mineral species are reported from the Froland pegmatites (Mindat, 2015b). However, their abundance, size and aesthetic quality is much lower and less developed than in the Evje-Iveland pegmatites. In connection with the application of the Tiin-quartz geothermobarometer (Huang and Audétat, 2012) it is essential to state here that the common Ti-bearing minerals in the Froland pegmatites include biotite, with $2.4 \pm 0.4$ wt.\% $\mathrm{TiO}_{2}$ (n=31; Müller et al., 2008a), rutile, ilmenite, titanite, euxenite, and aeschynite (Mindat, 2015b).

The pegmatites form large tabular bodies and dykes that occur both as weakly and complexly zoned bodies. They were emplaced within an isoclinally folded sequence of steeply dipping banded biotite-hornblende gneisses of volcanosedimentary origin, which underwent upper amphibolite to granulite facies Sveconorwegian metamorphism between 1145 and 1125 Ma (Cosca et al., 1998; Bingen et al., 2008b; Nijland et al., 2014). Peak P-T conditions in the granulite domain are consistently estimated at around $7 \mathrm{kbar}$ and $800^{\circ} \mathrm{C}$ (Nijland et al., 1993; Harlov, 2000). According to Nijland et al. (1993) and Cosca et al. 
(1998), the metamorphic peak was followed by an initial period of near isobaric cooling (2 bar $\left./{ }^{\circ} \mathrm{C}\right)$ followed by a period of near isothermal uplift $\left(30 \mathrm{bar} /{ }^{\circ} \mathrm{C}\right)$. This path is compatible with fluid inclusion data which suggests an amphibolite to granulite facies transition (Touret and Olsen, 1985). The evidence for initial isobaric cooling includes the presence of kyanitemuscovite veinlets in the Froland area, post-dating peak assemblages in the sillimanite stability field (Nijland et al., 1993). ${ }^{40} \mathrm{Ar} /{ }^{39} \mathrm{Ar}$ plateau ages for hornblende from 18 samples from the amphibolite and granulite-facies domains ranged from 1099 \pm 3 to $1079 \pm 5 \mathrm{Ma}$ with an average of $1089 \pm 3 \mathrm{Ma}$ (Cosca et al., 1998, and references therein). They indicate cooling of the pegmatite host rocks below $\sim 550^{\circ} \mathrm{C}$ at $\sim 1089 \mathrm{Ma}$ (Cosca et al., 1998). A cooling rate of 2 to $4^{\circ} \mathrm{C} / \mathrm{Ma}$ between $500^{\circ} \mathrm{C}$ and $300^{\circ} \mathrm{C}$ has been tentatively proposed by Cosca et al. (1998), using available biotite $\mathrm{K} / \mathrm{Ar}$ data. Using this pressure-temperature-time path, the host rock temperature during pegmatite emplacement at around $1060 \mathrm{Ma}$ was between $430^{\circ}$ and $490^{\circ} \mathrm{C}$ at pressures of $4 \pm 0.5 \mathrm{kbar}$ (Touret and Olsen, 1985; Cosca et al., 1998).

\subsection{Evje-Iveland pegmatites}

The Evje-Iveland pegmatite field is located in the Telemark lithotectonic domain, $25 \mathrm{~km}$ west of the PKFZ. The field trends N-S, it is some $30 \mathrm{~km}$ long, up to $10 \mathrm{~km}$ wide, and consists of more than 400 large $\left(>1000 \mathrm{~m}^{3}\right)$ pegmatite bodies. The pegmatites are hosted mainly by banded amphibole gneisses (1459 $\pm 8 \mathrm{Ma}$ Vånne banded gneiss), gabbroic amphibolites of the Iveland-Gautestad mafic intrusion $(1285 \pm 8$ to $1271 \pm 12 \mathrm{Ma}$ ), and by the Flåt-Mykleås metadiorite (1034 $\pm 2 \mathrm{Ma}$; Pedersen et al., 2009). These units provide a strong positive Bouguer anomaly below the pegmatite field (Gellein, 2007). A gadolinite U/Pb date from an unspecified pegmatite from the Evje-Iveland field yields an age of $910 \pm 14 \mathrm{Ma}$ (Scherer et al., 2001 ) and a monazite from another unspecified pegmatite gives a ${ }^{206} \mathrm{~Pb} /{ }^{238} \mathrm{U}$ age of $906 \pm 9 \mathrm{Ma}$ (Seydoux-Guillaume et al., 2012). The pegmatites are spatially associated with the Høvringsvatnet granite intrusion, located at the NE margin of the field (Fig. 3). However, zircon U/Pb dating demonstrates that the Høvringsvatnet pluton formed between $983 \pm 4$ and $980 \pm 4 \mathrm{Ma}$ and is thus temporally unrelated to the pegmatites (Snook, 2014).

According to the scheme of Cerný and Ercit (2005), the Evje-Iveland pegmatites are classified as rare-element REE and muscovite rare-element REE pegmatites consisting of $\mathrm{K}$ feldspar, plagioclase, quartz, biotite and muscovite, with minor magnetite and garnet. In addition, they contain more than 100 accessory rare metal and REE-bearing mineral species, including beryl, allanite, monazite, xenotime, zircon, gadolinite, fergusonite, columbite, and thortveitite (Mindat, 2015a, 2015c). Beside biotite, which contains $2.8 \pm 0.5$ wt. $\% \mathrm{TiO}_{2}(\mathrm{n}=4)$, the most common Ti-bearing minerals are rutile, ilmenite, titanite, euxenite, aeschynite, polycrase, and pyrochlore. The pegmatites are well zoned, consisting of a granitic wall facies, a megacrystic intermediate zone and core zone with massive quartz and feldspar which reaches crystal sizes of up to several meters. The pegmatites have NYF-type characteristics (Černý, 1991) but are poor in F. Some of the pegmatites exhibit late-pegmatitic (metasomatic), REE-depleted replacement zones consisting of "cleavelandite" (albite variety), "amazonite" (K-feldspar variety), quartz and muscovite and minor topaz, columbite, fluorite, garnet, beryl and tourmaline. These replacement zones have Lithium-CesiumTantalum (LCT) classification characteristics (Černý, 1991) and hence these pegmatites are considered as mixed NYF-LCT pegmatites. At the northern margin of the field, in the Landsverk area, three of the exposed pegmatites are brecciated and partially replaced by hydrothermal quartz, probably formed from fluids of largely meteoric origin (Snook, 2014). This event destroyed the primary zoning of the pegmatites and a new sequence of quartzalbite-epidote-stilpnomelane-pyrite-calcite-fluorite crystallized in open cavities. The 
mineralogy of the Evje-Iveland pegmatites has been described by Andersen (1931), Barth (1931, 1947) and Bjørlykke (1934, 1937). More recent studies were carried out by Frigstad (1999), Larsen (2002), Larsen et al. (2000b, 2004), Müller et al. (2012a), and Snook (2014).

From a regional perspective, the emplacement of the Evje-Iveland pegmatite field took place at the end of the Sveconorwegian orogeny at ca. $910 \mathrm{Ma}$, after a voluminous magmatic event which peaked at ca. $930 \mathrm{Ma}$ (Bingen et al., 2011; Fig. 4). This magmatism formed the Rogaland anorthosite-mangerite-charnockite (AMC) complex some $100 \mathrm{~km}$ west of EvjeIveland (Schärer et al., 1996; Vander Auwera et al., 2011). Estimated coeval (930-920 Ma) low-pressure high-temperature metamorphic conditions recorded in gneisses some $10 \mathrm{~km}$ east of the complex were ca. $760^{\circ} \mathrm{C}$ and $5.5 \mathrm{kbar}$ (M2 event) (Möller et al., 2002, 2003; Westphal et al., 2003; Bingen et al. 2008a, 2008b; Drüppel et al., 2013). A regional scale titanite U/Pb age cluster (12 samples) defines the timing of cooling through ca. $610^{\circ} \mathrm{C}$ at $918 \pm 2 \mathrm{Ma}$ (Bingen and van Breemen, 1998). A hornblende ${ }^{40} \mathrm{Ar} /{ }^{39} \mathrm{Ar}$ plateau age in six samples yields a cluster at $871 \pm 10 \mathrm{Ma}$ (Bingen et al., 1998). Together, the titanite and hornblende data point towards a slow and very late regional cooling between ca. 610 and $500^{\circ} \mathrm{C}$ in SW Telemark. Given these constraints, the interpolated pressure-temperature conditions during emplacement of the Evje-Iveland pegmatites were close to 600 to $550^{\circ} \mathrm{C}$ at 4 to $5 \mathrm{kbar}$.

\section{Samples and methods}

\subsection{Sampling}

The investigated pegmatites are well exposed in vertical and horizontal sections thanks to historic feldspar mining. At least one sample of megacrystic quartz was consistently collected from the intermediate zone of the pegmatites to ensure a comparable data set between pegmatite bodies. This sampling procedure was applied as it was determined, at an early stage in the investigations, that quartz from the Evje-Iveland pegmatites shows chemical variations within pegmatite bodies. Ninety pegmatites were sampled in the Froland area and 98 pegmatites in the Evje-Iveland area. Up to 18 samples were taken along 12 profiles crossing different zones of selected pegmatites in order to characterise the zonal distribution of quartz chemistry.

\subsection{Laser ablation inductively coupled plasma mass spectrometry}

Concentrations of $\mathrm{Li}, \mathrm{Be}, \mathrm{B}, \mathrm{Mn}, \mathrm{Ge}, \mathrm{Rb}, \mathrm{Sr}, \mathrm{Na}, \mathrm{Al}, \mathrm{P}, \mathrm{K}, \mathrm{Ca}, \mathrm{Ti}$, and Fe were determined by LA-ICP-MS. These elements are the most common trace elements in natural quartz (e.g., Götze et al., 2004; Götze, 2009; Rusk, et al., 2008; Müller et al. 2010b; Rusk, 2012). The quartz samples were prepared as surface-polished, 300- $\mu$ m-thick sections mounted on standard glass slides. The analyses were undertaken on a double-focusing sector field inductively coupled plasma mass spectrometer, HR-SF-ICP-MS, model ELEMENT XR from Thermo Scientific, which is linked to an excimer laser probe New Wave UP193FX ESI. The 193-nm laser had a repetition rate of $15 \mathrm{~Hz}$, a spot size of $75 \mu \mathrm{m}$, and energy fluence of about 5 to $6 \mathrm{~J} / \mathrm{cm}^{2}$ on the sample surface. A continuous raster ablation on an area of approximately $150 \times 300 \mu \mathrm{m}$ was applied. The approximate depth of ablation was between 10 and $50 \mu \mathrm{m}$. An Hitachi CCD video camera, type KP-D20BU, attached to the laser system, was used to observe the laser ablation process and to avoid micro mineral and fluid inclusions. Occasionally, however, individual fluid inclusions were hit in the current study, where it was not possible to find crystal domains entirely free of fluid inclusions, e.g. for samples from Løland and Åvesland 5 (Table A1). These analyses are recognizable from concentration 
spikes for $\mathrm{Na}, \mathrm{K}$ and/or $\mathrm{Ca}$. In general, however, total concentrations of lattice-bound trace elements determined by LA-ICP-MS are comparable with those from whole-sample analyses of the final quartz product, i.e. where advanced processing had removed almost all nonlattice-bound impurities (Müller, 2013).

The carrier gas for transport of the ablated material to the ICP-MS was He mixed with Ar. The isotope ${ }^{29} \mathrm{Si}$ was used as the internal standard applying the stoichiometric concentration of $\mathrm{Si}$ in $\mathrm{SiO}_{2}$. External multi-standard calibration was performed using three silicate glass reference materials produced by the National Institute of Standards and Technology, USA (NIST SRM 610, 612 and 614). In addition, the applied standards included the NIST SRM 1830 soda-lime float glass $\left(0.1 \% \mathrm{~m} / \mathrm{m} \mathrm{Al}_{2} \mathrm{O}_{3}\right)$, the certified reference material BAM No.1 amorphous $\mathrm{SiO}_{2}$ glass from the Federal Institute for Material Research and Testing in Germany and the Qz-Tu synthetic pure quartz monocrystal provided by Andreas Kronz from the Geowissenschaftliches Zentrum Göttingen (GZG), Germany. Certified, recommended and proposed values for these reference materials were taken from Jochum et al. (2011) and from the certificates of analysis where available. For the calculation of $P$ concentrations, the procedure of Müller et al. (2008b) was applied.

Each measurement comprised 15 scans of each isotope, with the measurement time varying from $0.15 \mathrm{~s} / \mathrm{scan}$ for $\mathrm{K}$ in medium mass resolution mode to $0.024 \mathrm{~s} / \mathrm{scan}$ of, e.g. $\mathrm{Li}$ in low mass resolution mode. An Ar blank was run before each reference material and sample measurement to determine of the background signal. The background was subtracted from the instrumental response of the reference material/sample before normalisation against the internal standard in order to avoid effects of instrumental drift. This was carried out to avoid memory effects between samples. A weighted least squares regression model, including several measurements of the six reference materials, was used to define the calibration curve for each element. Ten sequential measurements on the BAM No.1 $\mathrm{SiO}_{2}$ quartz glass were used to estimate the limits of detection (LOD) which were based on $3 \mathrm{x}$ standard deviation $(3 \sigma)$ of the 10 measurements. LOD's are listed in Table A1.

\section{Results}

\subsection{Quartz compositional variations between pegmatite fields}

$\mathrm{Al}, \mathrm{Ti}$ and $\mathrm{Ge}$ concentrations in quartz from the syn-orogenic Froland pegmatites are consistently low compared with those from other pegmatites in Norway (e.g., Götze et al., 2004) and world-wide (e.g., Breiter and Müller, 2009; Beurlen et al., 2011; Müller et al., 2013). Average concentrations of $\mathrm{Al}$ are $46 \pm 24 \mu \mathrm{gg}^{-1} \quad(\mathrm{n}=157), \mathrm{Ti} 7.6 \pm 2.9 \mu \mathrm{gg}^{-1}$ and $\mathrm{Ge}$ $1.4 \pm 0.8 \mu \mathrm{gg}^{-1}$ (Fig. 5). A characteristic feature of the Froland pegmatite quartz is its moderate to high Li content of $11.2 \pm 6.9 \mu \mathrm{gg}^{-1}$. Concentrations of $\mathrm{Be}, \mathrm{B}, \mathrm{Mn}, \mathrm{Rb}, \mathrm{Sr}, \mathrm{Na}, \mathrm{P}, \mathrm{K}, \mathrm{Ca}$ and Fe are mostly below detection limits (Table A1).

In the Evje-Iveland pegmatites, concentrations of $\mathrm{Al}$ (mean $69 \pm 57 \mu \mathrm{gg}^{-1} ; \mathrm{n}=228$ ), $\mathrm{Ti}$ $\left(19 \pm 11 \mu \mathrm{gg}^{-1}\right)$ and $\mathrm{Ge}\left(2.3 \pm 1.8 \mu \mathrm{gg}^{-1}\right)$ in quartz are much more variable and significantly higher compared with those from Froland. In particular Ti contents are very high, the highest average Ti content detected so far in pegmatite quartz (e.g., Müller et al., 2013). The average $\mathrm{Li}$ content of $6.8 \pm 4.6 \mu \mathrm{gg}^{-1}$ is relatively low for pegmatite quartz.

\subsection{Quartz compositional variations within pegmatite fields}

The distribution of $\mathrm{Ti}, \mathrm{Al}, \mathrm{Ge}$ and $\mathrm{Li}$ in pegmatite quartz from Froland shows important spatial patterns (Fig. 6). The highest Ti concentrations are observed immediately adjacent to 
and along the western border of the field, where the younger Holtebu and Herefoss granite plutons are situated (Figs. 3, 6A). Principally, Ge, Al and $\mathrm{Li}$ behave antithetically to Ti and are enriched along the SE and N border of the field, away from the PKFZ. Particularly high Li concentrations were detected in two clusters, in the Lauvland and Kråkevatnet areas (Fig. 6B). Al concentrations follow a similar pattern to Li. However, they are more scattered.

The regional distribution of $\mathrm{Ti}, \mathrm{Al}, \mathrm{Ge}$, and $\mathrm{Li}$ in quartz from the Evje-Iveland field is more irregular than in Froland. However, some significant patterns can be recognized. The most distinct feature is clustering of high Ge quartz in the central part of the pegmatite field, in the Birkeland, Frigstad and Li area (Fig. 7). These areas coincide with the highest density of chemically evolved pegmatites with "amazonite"-"cleavelandite" replacement zones. It is also the area with the highest known abundance of gadolinite- $(\mathrm{Y})\left(\mathrm{Y}_{2} \mathrm{Fe}^{2+} \mathrm{Be}_{2} \mathrm{Si}_{2} \mathrm{O}_{10}\right)$ worldwide (A. Omestad, pers. comm., 2013) with single crystals of more than $10 \mathrm{~kg}$ (Müller et al., 2010a). Gadolinite is a rare REE mineral which typically occurs in chemically evolved NYF-type pegmatites (e.g., Pezzotta et al., 1999). Quartz of the "amazonite"-"cleavelandite" pegmatites is not only enriched in $\mathrm{Ge}$ (mean $5.6 \pm 2.8 \mu \mathrm{gg}^{-1} ; \mathrm{n}=26$ ) but also in $\mathrm{Li}$ (mean

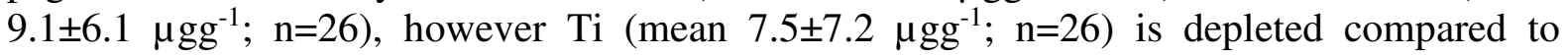
pegmatites elsewhere in the field. An area with high Ti and low Ge and Li quartz occurs at the northern margin of the field, at the same latitude as Evje. However, in the same area lie three brecciated and hydrothermally overprinted pegmatites, characterized by very low $\mathrm{Ti}$ of $<1.5 \mu \mathrm{gg}^{-1}$, very low $\mathrm{Ge}<0.2 \mu \mathrm{gg}^{-1}$, highly variable $\mathrm{Li}$, ranging from 0.9 to $27.4 \mu \mathrm{gg}^{-1}$ (mean $10.3 \pm 10.2 \mu \mathrm{gg}^{-1} ; \mathrm{n}=10$ ) and variable $\mathrm{Al}$ ranging from $8 \mu \mathrm{gg}^{-1}$ to $273 \mu \mathrm{gg}^{-1}$ (mean $71 \pm 84 \mu \mathrm{gg}^{-}$ $\left.{ }^{1}\right)$.

\subsection{Variations in quartz chemistry within individual pegmatites}

In order to assess variations in quartz chemistry within individual pegmatites, samples were analysed from traverses through different zones of representative pegmatite bodies from Froland and Evje-Iveland. Data from this was published by Müller et al. (2005, 2008a) and Snook (2014), but is repeated here as it is essential in: (1) evaluating the economic potential of the deposits; and (2) to better understand the genesis of the pegmatites (see section 5). Figure 8 shows one example traverse from each pegmatite field.

The Skåremyr pegmatite, which represents a typical simple zoned abyssal Froland pegmatite, shows almost no variation in quartz chemistry along a 35-m long traverse crossing the entire pegmatite body (Fig 10a in Müller et al. 2008a). Only Al increases slightly from the wall and intermediate zones $\left(34.7 \pm 2.3 \mu \mathrm{gg}^{-1}\right)$ towards the core zone $\left(43.2 \pm 1.4 \mu \mathrm{gg}^{-1}\right)$. For a number of other Froland pegmatites, no significant trend in quartz chemistry was detected (Müller et al., 2005, 2008a). However, mica and feldspar do show significant chemical variations and, therefore, these minerals seem more sensitive to pegmatite-internal fractionation processes.

In Evje-Iveland, quartz displays a very distinct trend within pegmatites. For example, the flat-lying Steli pegmatite (Fig. 8) is an asymmetrically zoned pegmatite with, from bottom to top, a lower border zone, a wall zone, a massive quartz core zone, a several meter thick intermediate zone, and a top border zone. Al and Ge concentrations in quartz increase systematically from the border zone, via the wall and core zone towards the intermediate zone. Ti behaves in the opposite way; it decreases from the border zone to the intermediate and core zone. Similar, but even higher, gradients in quartz chemistry from the border zone towards the core zone were described in Lithium-Cesium-Tantalum (LCT)-type pegmatites of Borborema, Brazil (Beurlen et al., 2011). 
Occasionally microscopic domains containing submicroscopic rutile needles (diameter $<0.5 \mu \mathrm{m}$; Fig. 9) occur in the investigated quartz, in particular in the samples from EvjeIveland. In general, it is suggested that this type of rutile needle is a product of epigenetic $\mathrm{TiO}_{2}$ exsolution of Ti from the quartz (e.g. Seifert et al., 2011). Several analyses were placed in rutile-bearing domains, in order to compare Ti concentrations of domains with and without rutile needles. The results indicate that there are no significant differences in the Ti content of rutile-bearing and rutile-free domains (Table A1).

\subsection{Application of Ti-in-quartz geothermobarometry}

Knowledge of the Ti activity in pegmatite melts is a prerequisite for the application of the Tiin-quartz geothermobarometer (see Huang and Audétat, 2012). The geothermobarometer is based on the temperature-pressure dependence of the $\mathrm{Ti}^{4+}-\mathrm{Si}^{4+}$ substitution in quartz in equilibrium with rutile, and allows the estimation of the crystallization temperature of the quartz if the pressure and Ti activity is known. Several lines of evidence indicate that the melts that formed the Froland and Evje-Iveland pegmatites were Ti saturated: 1) rutile is a common accessory mineral (Mindat, 2015a, 2015b, 2015c); 2) a value for $\mathrm{TiO}_{2}$ activity (aTiO2) of 1 was obtained using the method of Hayden and Watson (2007) for whole-rock geochemical data from 29 Froland and 17 Evje-Iveland pegmatites; 3) a value for aTiO2 of 1 was also obtained using the method of Ghiorso and Gualda (2013) on geochemical data from coexisting ilmenite and magnetite in the Birkeland 4 pegmatite, also called Røykkvartsbrudd or Knut Nateland Gruve, which is one of the most chemically evolved (low bulk $\mathrm{TiO}_{2}$ ) pegmatites in both fields. The $\mathrm{TiO}_{2}$ content in ilmenite is $48.1 \pm 1.2 \mathrm{wt}, \%(\mathrm{n}=10)$ and that of magnetite $0.2 \pm 0.1 \mathrm{wt} . \%$.

Correct application of the geothermobarometer requires evaluation as to the extent the diffusion of Ti in quartz may influence the calculated temperatures. Trace element diffusion can result in a significant redistribution of trace elements in quartz at high temperatures. Cherniak (2010) provided an overview of diffusivities of trace elements in quartz including $\mathrm{Ti}, \mathrm{Al}, \mathrm{Ga}, \mathrm{Ca}, \mathrm{K}, \mathrm{Na}$, and Li. According to Cherniak et al. (2007) the diffusion distance for $\mathrm{Ti}$ in quartz is c. $15 \mu \mathrm{m}$ in one million years at $600^{\circ} \mathrm{C}$. Diffusion rates for other substitutional ions (such as $\mathrm{Al}^{3+}$ and $\mathrm{Ga}^{3+}$ ) are in the same range, but are higher for interstitial ions (such as $\mathrm{Li}^{+}, \mathrm{K}^{+}, \mathrm{Na}^{+}$, and $\mathrm{Ca}^{2+}$ ). Considering the cooling history of the host rocks (Bingen et al., 1998; Cosca et al., 1998), the pegmatites of both fields cooled to below $400^{\circ} \mathrm{C}$ within one to three million years. At temperatures $<400^{\circ} \mathrm{C}$ the Ti diffusion distance is $<10 \mu \mathrm{m}$ in a hundred million years (Cherniak et al., 2007). Low Ti diffusion at c. $450^{\circ} \mathrm{C}$ is documented in wellpreserved (sharp) primary growth zoning developed in late-pegmatitic pocket quartz from a replacement zone of the Birkeland 3 pegmatite near Evje (Fig. 9; Müller, unpublished data). The sharpness of CL-contrasted growth zones is a strong criterion used for the assessment of the degree of Ti diffusion exchange in igneous quartz (Cherniak et al., 2007), because variations of the $\mathrm{Ti}$ content are the main cause for the CL-contrasted zoning in plutonic quartz (e.g., Müller et al., 2000). The analyzed quartz samples, which represent massive, anhedral pegmatite quartz from the intermediate zone with crystal sizes between $3 \mathrm{~cm}$ to $1 \mathrm{~m}$, show no primary growth zoning at thin section scale (Fig. 9). It cannot be discounted, however, that the growth zoning which developed originally within this quartz has subsequently been disturbed and redistributed by Ti diffusion over distances between 25 and $55 \mu \mathrm{m}$. In any case, element concentrations determined in this study are averaged over the volume of the laser ablation raster of $150 \times 300 \times 50 \mu \mathrm{m}$. Thus, the ablation raster is larger than the diffusion distance of $\mathrm{Ti}$ and other elements and element diffusion has, therefore, no significant effect on the interpretation of the presented data. 
Pressures used here to constrain temperatures of pegmatite crystallization are $4.0 \pm 0.5$ kbar for Froland and 4.5 \pm 0.5 kbar for Evje-Iveland, based on literature sources described in section 2 (Touret and Olsen, 1985; Cosca et al., 1998; Bingen and van Breemen, 1998; Möller et al., 2002, 2003; Bingen et al., 1998, 2008a, 2008b, Drüppel et al., 2013).

For the syn-orogenic pegmatites of Froland, the calculated crystallisation temperatures range from 471 to $617^{\circ} \mathrm{C}$, with an average of $537 \pm 39^{\circ} \mathrm{C}$. The highest crystallisation temperatures $\left(>550^{\circ} \mathrm{C}\right)$ occur predominantly along the NW margin of the pegmatite field in the immediate hanging wall of the PKFZ and close to the Holtebu granite (Fig. 10).

For quartz from the Evje-Iveland field, the calculated crystallisation temperature ranges from 442 to $731^{\circ} \mathrm{C}$, with an average of $613 \pm 70^{\circ} \mathrm{C}$, at a pressure of $4.5 \pm 0.5 \mathrm{kbar}$. Thus, the crystallization temperatures of quartz in the Evje-Iveland pegmatites are on average higher and more variable those of the Froland pegmatites. The regional distribution of Ti-in-quartz temperatures in Evje-Iveland appears irregular, mainly due to the scattered distribution of evolved "amazonite"-"cleavelandite" pegmatites, which show temperatures down to $442^{\circ} \mathrm{C}$. A cluster of these low temperature pegmatites occurs in the centre of the field but elsewhere they form strong, local temperature lows. The highest crystallisation temperatures were detected along the northern part of the Evje-Iveland field close to the Høvringsvatnet granite. However, two pegmatites within the Høveringsvatnet granite show moderate crystallisation temperatures, and do not substantiate the existence of a temperature gradient centered on this granite pluton. The three hydrothermally overprinted and brecciated pegmatites (green dots in Fig. 10) in the Landsverk area, in the central-northern margin of the field, exhibit very low crystallisation temperatures, $<400^{\circ} \mathrm{C}$, supporting a hydrothermal origin for quartz in these localities.

\section{Discussion}

\subsection{Petrogenetic and regional implications}

The two pegmatite fields studied show distinctive patterns in their quartz chemistry likely to be due to differences in their tectono-magmatic settings during pegmatite melt emplacement. According to Černy (1991) most pegmatites occur in groups or swarms. In a general model, it is assumed that pegmatitic melts become increasingly evolved with distance from a parental granite intrusion, if present (Černy, 1991). With increasing distance from the parental intrusion, pegmatites can show, therefore, enrichment in $\mathrm{Be}, \mathrm{Nb}, \mathrm{Ta} \mathrm{Li}, \mathrm{Cs}$ and volatiles, and more complex zoning. This results in a regional chemical-mineralogical zoning in groups of pegmatites around an associated intrusive. The zoning is influenced by the nature and structure of the host rock and the vertical level of exposure (erosional level).

\subsubsection{Genesis of the Froland pegmatite field}

The Froland pegmatite field shows an approximate evolutionary trend from NW to SE which is consistent with Černy's (1991) parental granite model. Contrary to the model however, no parental granite pluton has so far been identified for the Froland pegmatites, although this does not entirely preclude their occurrence at depth. The nature of the regional Bouguer anomaly field (Gellein, 2003) and the magnetic residual field (Sindre, 1992) do not give any evidence for a hidden parental granite. The time interval between 1100 and $1060 \mathrm{Ma}$, covering the emplacement of the Froland field, is a period of plutonic quiescence at the scale of the orogen (Bingen et al, 2008a, 2011; Fig. 4). However, lack of evidence is no proof of absence, and therefore the presence of a deep concealed parent granite pluton cannot be ruled 
out. The proximity of the pegmatite field to the PKZF (Fig. 3) and the regional pattern of the pegmatite crystallization temperatures rather suggest that the formation and emplacement of Froland pegmatite melts occurred in conjunction with the Sveconorwegian thrusting of the Bamble domain over the Telemark domain between 1100 and $1000 \mathrm{Ma}$ (Fig. 11A). Henderson and Ihlen (2004) suggested that pegmatitic melts were formed as a result of thrusting-enhanced crustal melting during progressive, sub-horizontal compressional deformation. This model is supported by the results of this study which show that the hottest $\left(>550^{\circ} \mathrm{C}\right)$ and least fractionated pegmatites occur predominantly along the NW margin of the pegmatite field, parallel to the PKFZ (Fig. 10). The cooler and more differentiated pegmatites occur along the SE margin of the field, away from the thrust zone. The clustering of high crystallization temperatures along the PKFZ suggests that the pegmatite melts were formed due to anatexis as a result of intense deformation and fluid migration/availability along the thrust (e.g., Henderson and Ihlen, 2004). Melts which migrated further away from the thrust, into the overlying gneiss complex, became relatively more fractionated (indicated by higher quartz Li contents), increasing their volatile contents and so lowering their crystallisation temperature, as indicted from low Ti in quartz.

The melting was presumably triggered by liberation of fluids along the thrust zone as described elsewhere (Le Fort et al., 1987; Druguet and Hutton, 1998; Berger et al., 2008; Genier et al., 2008). Henderson and Ihlen's (2004) observations that thrust-related isoclinal folding and pegmatite deformation occurred synchronously supports syn-thrusting melting for the formation of the pegmatite melts. The anatexis was presumably triggered and enhanced in zones of localized high-strain deformation and associated influx of aqueous fluids (e.g., Genier et al., 2008), with fluid-present melting evident from the high mica contents of the pegmatites (Milord et al., 2001). However, the difference between the temperatures of the host rocks $\left(430^{\circ}\right.$ and $490^{\circ} \mathrm{C}$ at c. $1060 \mathrm{Ma}$; Touret and Olsen, 1985; Cosca et al., 1998) and pegmatite melts $\left(537 \pm 39^{\circ} \mathrm{C}\right)$ suggests that the melts were generated at greater depth and then migrated upward to a shallower depth where they crystallized.

\subsubsection{Genesis of the Evje-Iveland pegmatites}

The Evje-Iveland pegmatites occur some $25 \mathrm{~km} \mathrm{~W}$ of the PKZF in the foot wall of the thrust zone. Because of their tectonostratigraphic position and young (post-thrusting) emplacement age, the thrust zone cannot be the origin of the pegmatite melts. The next most likely explanation for the formation of the Evje-Iveland pegmatites is that they represent evolved equivalents of nearby or underlying granitic bodies. However, the adjacent Høvringsvatnet granite, which lies to the NE of the pegmatite field, is ca. $70 \mathrm{Ma}$ older than the pegmatites and can therefore be excluded as a source of the melts (Snook, 2014). The closest granitic body with a similar emplacement age is the Herefoss granite (926 $\pm 8 \mathrm{Ma}$, Andersen, 1997). However, this is $18 \mathrm{~km} \mathrm{SE}$ of the pegmatite field and is therefore too far to be the parental pluton (Fig. 3).

As it is highly unlikely that the Evje-Iveland pegmatites formed either as a result of thrusting or shearing along the PKZF, or are genetically linked to nearby granites, an alternative mechanism is required for their genesis. Important in this discussion are the following characteristics of the Evje-Iveland pegmatites:

- The pegmatite field contains evolved mixed NYF-LCT type pegmatites, with replacement zones containing cleavelandite, amazonite, topaz, columbite etc., in close proximity to relatively primitive NYF pegmatites of almost abyssal character, containing allanite, monazite, euxenite etc. Both types were emplaced penecontemporaneously. 
- Both the evolved and primitive pegmatites are spatially associated with the IvelandGautestad amphibolites.

- Pegmatite K-feldspar from Evje-Iveland shows low initial ${ }^{87} \mathrm{Sr} /{ }^{86} \mathrm{Sr}$ values $(0.7063)$ (Stockmarr, 1994) implying a relatively juvenile source such as the mantle or partially melted mantle-derived protoliths, e.g. Iveland-Gautestad amphibolites.

- Based on detailed field observations in Barth (1947), and most recently in Snook (2014), the Iveland-Gautestad amphibolites show evidence of anatexis and the generation of pegmatite melts.

In the following discussion, formation of the Evje-Iveland pegmatites by local anatexis is considered. The emplacement of the pegmatites at 910 \pm 14 Ma (Scherer et al., 2001) and $906 \pm 9 \mathrm{Ma}$ (Seydoux-Guillaume et al., 2012) took place at the end of a period of voluminous late-orogenic magmatism during Sveconorwegian dilatation and relaxation, which peaked at ca. $930 \mathrm{Ma}$ (e.g., Vander Auwera et al., 2011). The late stage of the late-orogenic magmatism was accompanied by a low-pressure, high-temperature metamorphic event between 930 and $920 \mathrm{Ma}$ which was unique to the Telemark lithotectonic domain (Bingen et al., 2008b). The interpreted pressure and temperature conditions during the period of pegmatite formation were 4 to $5 \mathrm{kbar}$ and 600 to $550^{\circ} \mathrm{C}$. The heat responsible for this metamorphism and the widespread and voluminous late-orogenic magmatism in the Telemark lithotectonic domain can be explained by large-scale and long-lasting mafic underplating generating high heat flows (Hansen et al., 1996; Andersen et al., 2002b; Vander Auwera et al., 2011). The underplating of the lower crust east of the Evje-Iveland area is evident from the emplacement of juvenile, mantle-derived material, such as the $940 \mathrm{Ma}$ Tovdal granite and from the presence of distinct, mantle-derived components in the other granites (Andersen et al., 2002a, 2002b).

In the area of Evje-Iveland the underplating caused melting of the amphibolites and banded gneisses (Fig. 11C). Field observations and geochemical modelling by Snook (2014) indicate that the pegmatites formed by 15 to $30 \%$ partial melting of Iveland-Gautestad amphibolites. The estimated quartz crystallisation temperature $\left(613 \pm 70^{\circ} \mathrm{C}\right)$, which represents the minimum temperature of partial melting, is in the range of fluid-present partial melting of crustal rocks (650 to $700{ }^{\circ} \mathrm{C}$; e.g., Brown and Korhonen, 2009). However, the estimated regional temperature in rocks at the present level of exposure is slightly below the fluidpresent partial melting temperature indicating that at least some portions of the pegmatite melts were emplaced from greater depths. It is concluded that the Evje-Iveland pegmatites formed due to anatexis of metamorphosed intermediate and mafic rocks (amphibolites) of the Iveland-Gautestad intrusion. The water-rich pegmatite melts were probably too viscous to coalesce into large granitic intrusions and/or the sub-horizontal compressive stress regime did not allow for large-scale melt segregation, coalescence and transport.

\subsection{Economic implications}

The main reason for this extensive and long-term project was to identify potential HPQ deposits. According to the definition in Harben (2002), HPQ contains less than $50 \mu_{\mathrm{gg}^{-1}}$ impurities, however to be of economic interest deposits should also exceed a certain size (e.g., Müller et al., 2012b). Figure 12A illustrates the distribution of deposit size given as quartz resources in metric tonnes within the Froland field. The resource estimations were based on a survey of pegmatite size in the field and calculations of the modal quartz content using 46 pegmatite bulk analyses. The average modal quartz content of the Froland 
pegmatites is $29 \pm 4$ wt. $\%$ and that for the Evje-Iveland pegmatites $30 \pm 7$ wt.\%. For the resource estimations given in Table A2 and illustrated in Figures 12, 13 and 14 a minimum quartz content of $20 \mathrm{wt} . \%$ was applied considering that there will be no full recovery of quartz during processing. The average resource size of the investigated Froland pegmatites is approximately 350,000 tonnes quartz. The area east of Hynnekleiv (Fig. 12) has the greatest economic potential as it hosts the highest concentration of very large pegmatite bodies which each contain $>1$ million tonnes of quartz with a low average trace element content of $67 \pm 11$ $\mu \mathrm{gg}^{-1}$. Pegmatites in this area include Bjorvassheia Vest, Våtåskammen, Våtåstoppen, Nordre Våtåstjern, Gråkatt, Søndre Teigen and Nordre Teigen. The graph in Figure 13 illustrates the economic potential of quartz deposits determined from the chemical quality of quartz and deposit size, according to the scheme of Müller et al. (2012b). According to this classification, the large pegmatites in the Froland field, particularly in the Hynnekleiv area, can be graded as potentially economic.

Total trace element concentrations in quartz determined in this study represent in general the content of structurally incorporated trace elements. A quartz product with these concentrations of trace elements is only realised if advanced quartz processing technologies are applied; for example adhering to the Unimin Corporation (2014) and Quartz Corporation (2014) schemes. The average total trace element content of all investigated Froland pegmatites is $80 \pm 31{\mu g^{-1}}^{-1}$. Concentrations of $\mathrm{B}$ and $\mathrm{P}$ are mostly below the limits of detection (0.6 and $3 \mu \mathrm{gg}^{-1}$, respectively) and, thus, the quartz is suitable for the manufacture of photovoltaic and semiconductor products. One of the major economic advantages of the Froland pegmatites is their near homogenous quartz compositions within pegmatites bodies which, if advanced processing is applied, will produce predictable quartz qualities. The Kfeldspar in these pegmatites commonly contains $>13.0 \mathrm{wt} . \% \mathrm{~K}_{2} \mathrm{O}$ and low Fe which makes it suitable as a raw material for the ceramics industry (Ihlen et al., 2002). Thus, K-feldspar could be a valuable by-product of mining. Until 2011, Sibleco Nordic AS, and previous owners, mined the Glamsland pegmatite at Lillesand for quartz and potassic and sodic feldspar, the latter containing $>2.0$ wt. $\% \mathrm{CaO}$. In addition, xenotime concentrates were produced from biotite separates. The Glamsland pegmatite is of a similar type and age to the Froland pegmatites and both are part of the Bamble pegmatite district.

Economically, the outlook for the Evje-Iveland pegmatites is not so bright. Firstly, in general, they are smaller in size (mean $\sim 10,000 \mathrm{t}$ quartz), the quartz has higher total trace element concentrations (mean $129 \pm 108 \mu^{-1}$ ) and the concentrations vary from the margin to the core of the pegmatite bodies (Snook, 2014), which complicates the production of homogeneous quartz. The area showing the highest economic potential is the Li-FrikstadMølland area in the centre of the field (Fig. 14). It hosts the largest pegmatites, three of them containing $>50,000 \mathrm{t}$ quartz. Quartz from these pegmatites has average total trace element concentration of $128 \pm 64{\mu \mathrm{gg}^{-1}}^{-}$. However, none of the Evje-Iveland pegmatites plot in the field of economic potential (Fig. 13). In addition, these large pegmatites also show a strong internal chemical and mineralogical fractionation, hence a variable quartz chemistry (Fig. 8). Currently three pegmatites are mined at small scale for high quality K-feldspar and plagioclase. The feldspar lumps are hand-sorted and the annual production is less than $50 \mathrm{t}$. Sub-microscopic rutile needles occurring sporadically in quartz from Evje-Iveland would make the usage of the material inappropriate for silica glass production, because these inclusions can realistically not be removed by processing and will cause black spots and weakening of the glass. Critically however, the total trace element concentrations of EvjeIveland quartz are too high for such an application. A number of quartz samples from EvjeIveland contain 1 to $4 \mu \mathrm{gg}^{-1} \mathrm{~B}$ and 3 to $10 \mu \mathrm{gg}^{-1} \mathrm{P}$. Concentrations spikes $>10 \mu \mathrm{gg}^{-1}$ of $\mathrm{P}$ are considered to be caused by micro inclusions of apatite, monazite or xenotime. Quartz from 
evolved pegmatites which feature replacement zones has up to $7 \mu \mathrm{gg}^{-1} \mathrm{~B}$ (Table A1). Ideally $\mathrm{B}$ and $\mathrm{P}$ concentrations should be $1 \mu \mathrm{gg}^{-1}$ or less in quartz used for photovoltaic or semiconductor products (Blankenburg et al., 1994). About 35\% of the Evje-Iveland pegmatites do not fulfill this requirement.

\section{Conclusions}

In this study, the regional variation in quartz compositions across the Froland and EvjeIveland pegmatite fields was determined for the first time. The results necessitate a reevaluation of conventional thinking on how to explore for HPQ deposits in pegmatite fields and how pegmatite melts are formed if a parental granite intrusion is absent. The results can be summarized as follows:

1. Among the suite of analyzed trace elements $\mathrm{Al}, \mathrm{Ti}, \mathrm{Ge}$, and $\mathrm{Li}$ have elevated and genetically indicative concentrations in quartz. These elements have low concentrations in the Froland pegmatites compared to other pegmatites world-wide (e.g., Breiter and Müller, 2009; Beurlen et al., 2011; Müller et al., 2013) and their regional distribution shows a specific, relatively systematic pattern. Concentrations of these elements in quartz from the Evje-Iveland pegmatites are much more variable and significantly higher compared with quartz from Froland. In particular, Ti shows the highest average concentrations detected so far in pegmatite quartz (e.g., Müller et al., 2013). However, the distribution patterns are different from the classical model of concentric chemicalmineralogical zoning of pegmatite fields (e.g., Černy, 1991). This supports the interpretation that the pegmatites in both fields are genetically unrelated to large granite intrusions.

2. Pegmatites in the Evje-Iveland field show zoning with respect to quartz compositions characterized by enrichments in $\mathrm{Al}, \mathrm{Li}$, and $\mathrm{Ge}$ and depletion of $\mathrm{Ti}$ in pegmatite cores compared with wall and border zones. Pegmatites from Froland lack such zoning.

3. The average total trace element content of pegmatite quartz from Froland is $80 \pm 31 \mu \mathrm{gg}^{-}$ ${ }^{1}$ and the average quartz resource of a single pegmatite is about 350,000 t. From the spatial distribution of quartz chemistry and deposit size, the area east of Hynnekleiv is most prospective, containing pegmatites with $>1$ Mt of quartz which has some of the lowest total trace element contents (mean $67 \pm 11 \mu \mathrm{gg}^{-1}$ ). These pegmatites have the greatest potential to produce quartz products of high intermediary quality if advanced processing is applied (Fig. 12). One of the major economic advantages is the almost homogeneous intrinsic quartz chemistry of the Froland pegmatites which will produce a homogeneous quartz product. K-feldspar in the Froland pegmatites commonly has $>13.0 \mathrm{wt} . \% \mathrm{~K}_{2} \mathrm{O}$ and can could thus serve as a valuable by-product. The Evje-Iveland pegmatites are smaller in size (mean about 10,000 $\mathrm{t}$ quartz), they are zoned with respect to quartz chemistry and their quartz has higher total trace element concentrations (mean $129 \pm 108 \mu \mathrm{gg}^{-1}$ ) compared to Froland pegmatites. The Evje-Iveland pegmatites have currently no economic potential if only quartz is mined. However, because of ongoing selective mining of high quality K-feldspar and plagioclase in some of the pegmatites, quartz of intermediary quality could be a by-product.

4. The application of the Ti-in-quartz geothermobarometer (adapted by Huang and Audétat, 2012) revealed that the pegmatites of Froland crystallized at temperatures between 471 and $617^{\circ} \mathrm{C}$ with an average of $537 \pm 39^{\circ} \mathrm{C}$. The highest crystallisation temperatures $\left(>550^{\circ} \mathrm{C}\right)$ occur predominantly along the $\mathrm{NW}$ margin of the Froland pegmatite field close to the PKFZ. The range of crystallisation temperatures in the 
Evje-Iveland pegmatites varies from 442 to $731^{\circ} \mathrm{C}$ with an average of $613 \pm 70^{\circ} \mathrm{C}$. Spatially variable temperatures in the Evje-Iveland field appear to be due to the scattered distribution of evolved pegmatites which have commonly low crystallisation temperatures down to $442^{\circ} \mathrm{C}$.

5. Melts forming the Froland pegmatites were generated by fluid-present crustal melting in zones of localized high-strain deformation during progressive thrusting along the PKFZ at about $1060 \mathrm{Ma}$. The hottest and least fractionated pegmatite melts crystallised close to the PKFZ but originated from a greater depth than represented by the current level of exposure. Cooler and more differentiated pegmatites occur away from the thrust zone. In the Evje-Iveland field, a low-pressure/high-temperature event (930-920 Ma) triggered partial melting of amphibolites which resulted in the formation of pegmatites which were emplaced at or close to where they currently lie. The heat responsible for this event, together with late-orogenic magmatism in the Telemark lithotectonic domain, was likely produced by mafic crustal-underplating (Andersen et al., 2002b; Vander Auwera et al., 2011).

\section{Acknowledgements}

We like to thank Arild Omestad and Andreas Korneliussen for fruitful discussions in the field about the mineralogy and historical mining in the Evje-Iveland district. Rolf Romer deserves special thanks for his comments on an earlier version of the manuscript. We are grateful to Brian Rusk, David London and one anonymous reviewer for their constructive comments and suggestions which have greatly improved the quality of the manuscript. The study was financially and logistically supported by the Geological Survey of Norway in Trondheim through several projects. 


\section{References}

Andersen, O., 1926, Feltspat I: Norges Geologiske Undersøkelse, v. 128a, p. 1-142. (in Norwegian)

Andersen, O., 1931, Feltspat II. Norges Geologiske Undersøkelse: v. 128b, p. 1-109. (in Norwegian).

Andersen, T., 1997, Radiogenic isotope systematics of the Herefoss Granite, South Norway; an indicator of Sveconorwegian (Grenvillian) crustal evolution in the Baltic Shield: Chemical Geology, v. 135, p. 139-158.

Andersen, T., Griffin, W.L., Jackson, S.E., Knudsen, T.L., and Pearson, N.J., 2004, MidProterozoic magmatic arc evolution at the southwest margin of the Baltic shield: Lithos, v. 73, p. 289-318.

Andersen, T., Andresen, A., and Sylvester, A.G., 2002a, Timing of late- to post-tectonic Sveconorwegian granitic magmatism in south Norway: Norges Geologiske Undersøkelse Bulletin, v. 440, p. 5-18.

Andersen, T., Griffin, W.L., and Pearson, N.J., 2002b, Crustal evolution in the SW part of the Baltic Shield: the Hf isotope evidence: Journal of Petrology, v. 43, p. 1725-1747.

Åmli, R., 1977, Internal structure and mineralogy of the Gloserhei granite pegmatite, Froland, southern Norway: Norsk Geologisk Tidsskrift, v. 57, p. 243-262.

Audétat, A., 2013, Origin of Ti-rich rims in quartz phenocrysts from the Upper Bandelier Tuff and the Tunnel Spring Tuff, southwestern USA: Chemical Geology, v. 360-361, p. 99-104.

Baadsgaard, H., Chaplin, C., and Griffin, W.L., 1984, Geochronology of the Gloserheia pegmatite, Froland, southern Norway: Norsk Geologisk Tidsskrift, v. 64, p. 111-119.

Barth, T.F.W., 1931, Feltspat III. Forekomster i Iveland og Vegusdal i Aust-Agder og herreder i Vest-Agder: Norges Geologiske Unders $\varnothing$ kelse, v. 128b, p. 1-170. (in Norwegian)

Barth, T.F.W., 1947, The nickeliferous Iveland-Evje amphibolites and its relation: Norges Geologiske Undersøkelse, v. 168a, p.1-71.

Berger, A., Burri, T., Alt-Epping, P., and Engi, M., 2008, Tectonically controlled fluid flow and water assisted melting in the middle crust: An example from the central Alps: Lithos, v. 102, p. 598-615.

Beurlen, H., Müller, A., Silva, D., and Da Silva, M.R.R., 2011, Petrogenetic significance of LA-ICP-MS trace-element data on quartz from the Borborema Pegmatite Province, northeast Brazil: Mineralogical Magazine, v. 75, p. 2703-2719.

Bingen, B., and van Breemen, O., 1998, U-Pb monazite ages in amphibolite- to granulitefacies orthogneisses reflect hydrous mineral breakdown reactions: Svegonorwegian Province of SW Norway: Contributions to Mineralogy and Petrology, v. 132, p. 336353.

Bingen, B., Boven, A., Punzalan, L., Wijbrans, J., and Demaiffe, D., 1998, Hornblende ${ }^{40} \mathrm{Ar} /{ }^{39} \mathrm{Ar}$ geochronology across terrane boundaries in the Sveconorwegian province of S Norway: Precambrian Research, v. 90, p. 159-185.

Bingen, B., Nordgulen, Ø., and Viola, G., 2008a, A four phase model for the Sveconorwegian orogeny, SW Scandinavia: Norwegian Journal of Geology, v. 88, p. 43-72.

Bingen, B, Davis W.J, Hamilton M.A., Engvik A.K., Stein H.J., Skår Ø., and Nordgulen, Ø., 2008b, Geochronology of high-grade metamorphism in the Sveconorwegian belt, S. Norway: U-Pb, Th-Pb and Re-Os data: Norwegian Journal of Geology, v. 88, p. 13-42. 
Bingen, B., Belousova, E.A., and Griffin, W.L., 2011, Neoproterozoic recycling of the Sveconorwegian orogenic belt: detrital-zircon data from the Sparagmite basins in the Scandinavian Caledonides: Precambrian Research, v. 189, p. 347-367.

Bjørlykke, H., 1934, The mineral paragenesis and classification of the granite pegmatites of Iveland, Setesdal, southern Norway: Norsk Geologisk Tidsskrift, v. 14, p. 211-311.

Bjørlykke, H., 1937, The granite pegmatites of southern Norway: American Mineralogist, v. 22, p. 241-255.

Blankenburg, H.-J., Götze, J. and Schulz, H., 1994, Quarzrohstoffe. Deutscher Verlag für Grundstoffindustrie, Leipzig-Stuttgart, p. 296. (in German)

Breiter, K., and Müller, A., 2009, Evolution of rare-metal granitic magmas documented by quartz chemistry: European Journal of Mineralogy, v. 21, p. 335-346.

Breiter K., Ackerman L., Svojtka M. and Müller A., 2013, Behavior of trace elements in quartz from plutons of different geochemical signature: A case study from the Bohemian Massif, Czech Republic: Lithos, v. 175-176, p. 54-67.

Brown, M., and Korhonen, F.J., 2009, Some remarks on melting and extreme metamorphism of crustal rocks, in Dasgupta, S., ed., Physics and Chemistry of the Earth: New York, Published for the Indian National Science Academy by Springer, p. 67-87.

Cosca, M.A., Mezger, K., and Essene, E.J., 1998, The Baltica-Laurentia connection: Sveconorwegian (Grenvillian) metamorphism, cooling, and unroofing in the Bamble sector, Norway: Journal of Geology, v. 106, p. 539-552.

Černy, P., 1991, Rare-element granitic pegmatites. Part 1: Anatomy and internal evolution of pegmatite deposits. Part 2: Regional to global environments and petrogenesis: Geoscience Canada, v. 18, p. 49-81.

Černy, P., 1994, Evolution of feldspars in granitic pegmatites, in Parson, I., ed., Feldspars and their reactions, NATO Advanced Study Institute, Series C 421, p. 501-539.

Černý, P., and Ercit, T.S., 2005, The classification of granitic pegmatites: Canadian Mineralogist, v. 43, p. 2005-2026.

Černý, P., Meintzer, R.E., and Anderson, A.J., 1885, Extreme fractionation in rare-element granitic pegmatites: Selected examples of data and mechanisms: Canadian Mineralogist, v. 23, p. 381-421.

Cherniak, D.J., 2010, Diffusion in quartz, melilite, silicate perovskite, and mullite, in Zhang, Y. and Cherniak, D.J., eds, Diffusion in minerals and melts, Reviews of Mineralogy and Geochemistry, v. 72, p. 735-756.

Cherniak, D.J., Watson, E.B. and Wark, D.A., 2007, Ti diffusion in quartz: Chemical Geology, v. 236, p. 65-74.

Dupont, A., 2004, Pétrologie, géochimie et géochimie isotopique du massif de Farsund (Norvège): implications pour le magmatisme AMCG. PhD thesis. Department of Geology, Liège University, Belgium. (in French)

Druguet, E., and Hutton, D.H.W., 1998, Syntectonic anatexis and magmatism in a midcrustal transpressional shear zone: an example from the Hercynian rocks of the eastern Pyrenees: Journal of Structural Geology, v. 20, p. 905-916.

Drüppel, K., Elsässer, L., Brandt, S., and Gerdes, A., 2013, Sveconorwegian mid-crustal ultrahigh-temperature metamorphism in Rogaland, Norway: U-Pb LA-ICP-MS geochronology and pseudosections of sapphirine granulites and associated paragneisses: Journal of Petrology, v. 54, p. 305-350.

Flem, B., Larsen, R.B., Grimstvedt, A., and Mansfeld, J. 2002, In situ analysis of trace elements in quartz by using laser ablation inductively coupled plasma mass spectrometry: Chemical Geology, v. 182, p. 237-247. 
Frigstad, O.F., 1999, Amazonittpegmatitter i Iveland-Evje: Bergverksmuseets Skrift, v. 15, p. 60-73. (in Norwegian)

Ghiorso, M.S., and Gualda G.A.R., 2013, A method for estimating the activity of titania in magmatic liquids from the compositions of coexisting rhombohedral and cubic irontitanium oxides: Contributions to Mineralogy and Petrology, v. 165, p. 73-81.

Gellein, J., 2003, Gravimetrisk residualkart, Arendal. Målestokk 1 : 250000: Norges Geologiske Undersøkelse, Trondheim, Norway.

Gellein, J., 2007, Gravimetrisk residualkart, Mandal, Målestokk 1 : 250000: Norges Geologiske Undersøkelse, Trondheim, Norway.

Genier, F., Bussy, F., Epard, J.-L., and Baumgartner, L., 2008, Water-assisted migmatization of metagreywackes in a Variscan shear zone, Aiguilles-Rouges massif, western Alps: Lithos, v. 102, p. 575-597.

Götte, T., Ramseyer, K., Pettke, T. and Koch-Müller M., 2013, Implications of trace element composition of syntaxial quartz cements for the geochemical conditions during quartz precipitation in sandstones: Sedimentology, v. 60, p. 1111-1127.

Götze, J., 2009, Chemistry, textures and physical properties of quartz - geological interpretation and technical application: Mineralogical Magazine, v. 73, p. 645-671.

Götze, J. and Plötze, M., 1997, Investigation of trace-element distribution in detrital quartz by electron paragenetic resonance (EPR): European Journal of Mineralogy, v. 9, p. 529537.

Götze, J., Plötze, M., Graupner, T., Hallbauer, D.K. and Bray, C., 2004, Trace element incorporation into quartz: a combined study by ICP-MS, electron spin resonance, cathodoluminescence, capillary ion analysis and gas chromatography: Geochimica et Cosmochimica Acta, v. 68, p. 3741-3759.

Götze, J., Plötze, M., and Trautmann, T., 2005, Structure and luminescence characteristics of quartz from pegmatites: American Mineralogist, v. 90, p. 13-21.

Götze, J., 2012, Mineralogy, geochemistry and cathodoluminescence of authigenic quartz from different sedimentary rocks, in Götze, J. and Möckel, R., eds., Quartz: Deposits, mineralogy and analytics, Springer Geology, Berlin, Heidelberg, p. 287-306.

Hansen, K., Pedersen, S., Fought, H., and Stockmarr, P., 1996, Post Sveconorwegian uplift and cooling history of the Evje area, southern Setesdal, Central South Norway: Norges Geologiske Undersøkelse Bulletin, v. 431, p. 49-58.

Harben, P.W., 2002, The industrial mineral handybook - a guide to markets, specifications and prices: 4th edition, Industrial Mineral Information, Worcester Park, United Kingdom, $412 \mathrm{p}$.

Harlov, D.E., 2000, Pressure-temperature estimation in orthopyroxene-garnet bearing granulite facies rocks, Bamble Sector, Norway: Mineralogy and Petrology, v. 69, p. 1133.

Haus, R., 2005, High demands on high purity: Industrial Minerals, v. 10, p. 62-67.

Haus, R., Prinz, S., and Priess, C., 2012, Assessment of high purity quartz resources, in Götze, J. and Möckel, R., eds., Quartz: Deposits, mineralogy and analytics, Springer Geology, Berlin, Heidelberg, p. 29-51.

Hayden, L.A., and Watson, E.B., 2007, Rutile saturation in hydrous siliceous melts and its bearing on Ti-thermometry of quartz and zircon: Earth Planetary Science Letters, v. 258, p. 561-568.

Henderson, I., and Ihlen, P.M., 2004, Emplacement of polygeneration pegmatites in relation to Sveco-Norwegian contractional tectonics: examples from southern Norway: Precambrian Research, v. 133, p. 207-222. 
Holland, T.J.B., Babu, E.V.S.S.K., and Waters, D.J., 1996, Phase relations of osumilite and dehydration melting in pelitic rocks: a simple thermodynamic model for the KFMASH system: Contributions to Mineralogy and Petrology, v. 124, p. 383-394.

Huang, R., and Audétat, A., 2012, The titanium-in-quartz (TitaniQ) thermobarometer: A critical examination and re-calibration: Geochimica et Cosmochimica Acta, v. 84, p. 75-89.

Ihlen, P.M., Lynum, R., Henderson, I., and Larsen, R.B., 2001, Potensielle ressurser av kvarts- og feldspat- råstoffer på Sørlandet, I: Regional prøvetaking av utvalgte feltspatbrudd i Frolandsområdet: Norwegian Geological Survey Report 2001.044, Trondheim, Norway, 46 p. (in Norwegian).

Ihlen, P.M., Henderson, I., Larsen, R.B., and Lynum, R., 2002, Potensielle ressurser av kvarts- og feldspat- råstoffer på Sørlandet, II: Resultater av undersøkelsene i Frolandsområdet i 2001: Norwegian Geological Survey Report 2002.009, Trondheim, Norway, 100 p. (in Norwegian).

Jacamon, F. and Larsen, R.B., 2009, Trace element evolution of quartz in the charnockitic Kleivan granite, SW-Norway: the Ge/Ti ratio of quartz as an index of igneous differentiation: Lithos, v. 107, p. 281-291.

Jochum, K.P., Weis, U., Stoll, B., Kuzmin, D., Yang, Q., Raczek, I., Jacob, D.E., Stracke, A., Birbaum, K., Frick, D.A., Günther, D. and Enzweiler, J., 2011, Determination of Reference Values for NIST SRM 610-617 Glasses Following ISO Guidelines: Geostandards and Geoanalytical Research, v 35, p. 397-429.

Kidder, S., Avouac, J.-P. and Chan, Y.-C., 2013, Application of titanium-in-quartz thermobarometry to greenschist facies veins and recrystallized quartzites in the Hsüehshan range, Taiwan: Solid Earth, v. 4, p. 1-21.

Kullerud, L., and Dahlgren, S.H., 1993, Sm-Nd geochronology of Sveconorwegian granulite facies mineral assemblages in the Bamble shear belt, south Norway: Precambrian Research, v. 64, p. 389-402.

Larsen, R.B., 1999, Distribution of Al, Li, and Na in granite pegmatite quartz from EvjeIveland and Froland: Norwegian Geological Survey Report 1999.126, Trondheim, Norway, 16 p.

Larsen, R.B., 2002, The distribution of rare-earth elements in K-feldspars as an indicator of petrogenetic processes in granitic pegmatites: Examples from two pegmatite fields in southern Norway: Canadian Mineralogist, v. 40, p. 137-151.

Larsen, R.B., Flem, B., Dundas, S., Lahaye, Y., and Mansfeld, J., 2000a, LA-HR-ICP-MS analysis of quartz and principles governing the distribution and speciation of strcutural impurities in igneous quartz: Norwegian Geological Survey Report 2000.081, Trondheim, Norway, $43 \mathrm{p}$.

Larsen, R.B., Polvè, M., and Juve, G., 2000b, Granite pegmatite quartz from Evje-Iveland: trace element chemistry and implications for the formation of high-purity quartz: Norges Geologiske Undersøkelse Bulletin, v. 436, p. 57-65.

Larsen, R.B., Henderson, I., and Ihlen, P.M., 2004, Distribution and petrogenetic behaviour of trace elements in granitic pegmatite quartz from South Norway: Contributions to Mineralogy and Petrology, v. 147, p. 615-628.

Le Fort, P., Cuney, M., Deniel, C., France-Lanord, C., Sheppard, S.M.F., Upreti, B.N., and Vidal, P., 1987, Crustal generation of the Himalayan leucogranites: Tectonophysics, v. 134, p. 39-57.

Maydagán, L., Francini, M., Rusk, B., Lentz, D., McFarlane, C., Impiccini, A., Rios, F., and Rey, R., 2015, Porphyry to epithermal transition in the Altar $\mathrm{Cu}-(\mathrm{Au}-\mathrm{Mo})$ deposit, 
Argentina, studied by cathodoluminescence, LA-ICPMS, and fluid inclusions: Economic Geology, in press.

Milord, I., Sawyer, E.W., and Brown, M., 2001, Formation of diatexite migmatite and granite magma during anatexis of semipelitic metasedimentary rocks: An example from St. Malo, France: Journal of Petrology, v. 42, p. 487-505, doi:10.1093/petrology/42.3.487.

Mindat, 2015a, Evje og Hornnes, Aust-Agder, Norway. <http://www.mindat.org/loc5491.html> Accessed 2 February 2015.

Mindat, 2015b, Froland, Aust-Agder, Norway. <http://www.mindat.org/loc-2456.html> Accessed 2 February 2015.

Mindat, 2015c, Iveland, Aust-Agder, Norway. <http://www.mindat.org/loc-32512.html> Accessed 2 February 2015.

Möller, A., O’Brien, P.J., Kennedy, A., and Kröner, A., 2002, Polyphase zircon in ultrahightemperature granulites (Rogaland, SW Norway): constraints for $\mathrm{Pb}$ diffusion in zircon: Journal of Metamorphic Geology, v. 20, p. 727-740.

Möller, A., O’Brien, P.J., Kennedy, A., and Kröner, A., 2003, Linking growth episodes of zircon and metamorphic textures to zircon chemistry: an example from the ultrahightemperature granulites of Rogaland (SW Norway). In Vance, D., Müller, W. \& Villa, I.M. (eds.), Geochronology: linking the isotopic record with petrology and textures: Geological Society, London, Special Publications, v. 220, p. 65-81.

Mulch, A., Cosca, M., Andresen, A., and Fiebig, J., 2005, Time scales of deformation and exhumation in extensional detachment systems determined by high-spatial resolution in situ UV-laser ${ }^{40} \mathrm{Ar} /{ }^{39} \mathrm{Ar}$ dating: Earth and Planetary Science Letters, v. 233, p. 375-390.

Müller, A., 2013, Final report summarizing field and analytical work on alaskite deposits of the Spruce Pine district in 2012 and 2013: The Quartz Corp Report, 13th November 2013, $142 \mathrm{p}$.

Müller, A. and Knies, J., 2013, Trace elements and cathodoluminescence of detrital quartz in Arctic marine sediments - a new ice-rafted debris provenance proxy: Climate of the Past, v. 9, p. 2615-2630.

Müller A., Seltmann R. and Behr H.-J., 2000, Application of cathodoluminescence to magmatic quartz in a tin granite - case study from the Schellerhau Granite Complex: Mineralium Deposita, v. 25, p. 169-189.

Müller, A., Wiedenbeck, M., van den Kerkhof, A.M., Kronz, A., and Simon, K., 2003, Trace elements in quartz - a combined electron microprobe, secondary ion mass spectrometry, laser-ablation ICP-MS, and cathodoluminescence study: European Journal of Mineralogy, v. 15, p. 747-763.

Müller, A., Ihlen, P.M., and Kronz, A., 2005, Potential resources of quartz and feldspar raw material in Sørland IV: Relationships between quartz, feldspar and mica chemistry and pegmatite type: Norwegian Geological Survey Report 2005.075, Trondheim, Norway. (in Norwegian)

Müller, A., Ihlen, P.M., and Kronz, A., 2008a, Quartz chemistry in polygeneration Sveconorwegian pegmatites, Froland, Norway: European Journal of Mineralogy, v. 20, p. 447-463.

Müller, A., Wiedenbeck, M., Flem, B., and Schiellerup, H., 2008b, Refinement of phosphorus determination in quartz by LA-ICP-MS through defining new reference material values: Geostandards and Geoanalytical Research, v. 32, p. 361-376.

Müller, A., Rumsey, M., and Ihlen, P.M., 2010a, Pegmatittmineraler fra Evje-Iveland i samlingen til Naturhistorisk Museum i London: Stein, v. 4, p. 8-14. (in Norwegian) 
Müller, A., van den Kerkhof, A.M., Behr, H.-J., Kronz, A. and Koch-Müller, M., 2010b, The evolution of late-Hercynian granites and rhyolites documented by quartz - a review: Geological Society of America Special Papers, v. 472, p. 185-204.

Müller, A., Kearsley, A., Spratt, J., and Seltmann, R., 2012a, Petrogenetic implications of magmatic garnet in granitic pegmatites from southern Norway: Canadian Mineralogist, v. 50, p. 1095-1115.

Müller, A., Wanvik, J. E., and Ihlen, P.M., 2012b, Petrological and chemical characterisation of high-purity quartz deposits with examples from Norway, in Götze, J. and Möckel, R., eds., Quartz: Deposits, mineralogy and analytics, Springer Geology, Berlin, Heidelberg, p. 71-118.

Müller, A., Snook, B., Ihlen, M.P., Beurlen, H., and Breiter, K., 2013, Diversity of the quartz chemistry of NYF- and LCT-type pegmatites and its economic implications. Mineral deposit research for a high-tech world: Proceedings of the 12th Biennial SGA Meeting, v. 4, 12-15 August 2013, Uppsala, Sweden, ISBN 978-91-7403-207-9, p. 1774-1776.

Neiva, A.M.R., 1995, Distribution of trace elements in feldspars granitic aplites and pegmatites from Alijó-Sanfins, northern Portugal: Mineralogical Magazine, v. 59, p. $35-45$.

Nijland, T.G., Liauw, F., Visser, D., Maijer C., and Senior, A., 1993, Metamorphic petrology of the Froland corundum-bearing rocks: The cooling and uplift history of the Bamble Sector, South Norway: Norges Geologiske Undersøkelse, v. 424, p. 51-64.

Nijland, T.G., Harlov, D.E. and Andersen, T., 2014, The Bamble Sector, south Norway: A review: Geoscience Frontiers, v. 5, p. 635-658.

Pedersen, S. 1981, Rb/Sr age determinations on the late Proterozoic granitoids from the Evje area, south Norway: Bulletin of the Geological Society of Denmark (29): 129-143.

Pedersen, S., Andersen, T., Konnerup-Madsen, J., and Griffin, W.L., 2009, Recurrent mesoproterozoic continental magmatism in south-central Norway: International Journal of Earth Sciences, v. 98, p. 1151-1171.

Pezzotta, F., Diella, V., and Guastoni, V. A., 1999, Chemical and paragenetic data on gadolinite-group minerals from Baveno and Cuasso al Monte, southern Alps, Italy: American Mineralogist, v. 84, p. 782-789.

Quartz Corporation, 2014, <http://www.thequartzcorp.com/en/products/high-purityquartz.html> Accessed 2 May 2014.

Rusk B., 2012, Cathodoluminescence and trace elements in hydrothermal quartz, in Götze, J. and Möckel, R., eds., Quartz: Deposits, mineralogy and analytics, Springer Geology, Berlin, Heidelberg, p. 307-329.

Rusk, B., 2014, Quartz cathodoluminescence: Textures, trace elements, and geologic applications, in Coulson, I. and Robinson, M., eds., Laser ablation ICP-MS in the Earth Sciences: Current practices and outstanding issues; Fredericton, New Brunswick, Mineralogical Association of Canada, Short Course 45, p. 147-168.

Rusk, B., Reed, M., H., Dilles, J. H. and Kent, A. J. R., 2006, Intensity of quartz cathodoluminescence and trace-element content in quartz from the porphyry copper deposit at Butte, Montana: American Mineralogist, v. 91, p. 1300-1312.

Rusk, B., Lowers, H., and Reed, M., 2008, Trace elements in hydrothermal quartz; relationships to cathodoluminescent textures and insights into hydrothermal processes: Geology, v. 36, p. 547-550.

Rusk, B., Koenig, A., and Lowers, H., 2011, Visualizing trace element distribution in quartz using cathodoluminescence, electron microprobe, and laser ablation-inductively coupled plasma-mass spectrometry: American Mineralogist, v. 96, p. 703-708. 
Schärer, U., Wilmart, E., and Duchesne, J.-C., 1996, The short duration and anorogenic character of anorthosite magmatism: U-Pb dating of the Rogaland complex, Norway: Earth and Planetary Science Letters, v. 139, p. 335-350.

Scherer, E, Münker, C, and Mezger, K., 2001, Calibration of the lutetium-hafnium clock: Science, v. 293, p. 683-687.

Schrön, W., Schmädicke, E., Thomas, R., and Schmidt, W., 1988, Geochemische Untersuchungen an Pegmatitquarzen: Zeitschrift der Geologischen Wissenschaften, v. 16, p. 229-244. (in German)

Seifert, W., Rhede, D., Thomas, R., Förster, H.-J., Lucassen, F., Dulski. P., and Wirth, R., 2011, On the origin of igneous blue quartz: inferences from a multi-analytical study of submicron mineral inclusions: Mineralogical Magazine, v. 75, p. 2519-2534.

Seydoux-Guillaume, A.M., Montel, J.M., Bingen, B., Bosse, V., de Parseval, P., Paquette, J.L., Janots, E., and Wirth, R., 2012, Low-temperature alteration of monazite: Fluid mediated coupled dissolution-precipitation, irradiation damage, and disturbance of the $\mathrm{U}-\mathrm{Pb}$ and Th-Pb chronometers: Chemical Geology, v. 330-331, p. 140-158.

Sindre, A., 1992, Regional tolkning av geofysiske data, kartblad Arendal, M 1:250000: Norwegian Geological Survey Report 92.213, Trondheim, Norway, 30 p. (in Norwegian).

Smeds, S.-A., 1992, Trace elements in potassium-feldspar and muscovite as a guide in the prospecting for lithium- and tin-bearing pegmatites in Sweden: Journal of Geochemical Exploration, v. 42, p. 351-369.

Snook, B., 2014, Towards exploration tools for high purity quartz: an example from the South Norwegian Evje-Iveland pegmatite belt: PhD thesis, Camborne School of Mines, University of Exeter, UK.

Spear, F. S., and Wark, D. A., 2009, Cathodoluminescence imaging and titanium thermometry in metamorphic quartz: Journal of Metamorphic Geology, v. 27, p. 187205.

Starmer, I.C., 1993, The Sveconorwegian orogeny in southern Norway, relative to deep crystal structures and events in the North Atlantic Proterozoic supercontinent: Norsk Geologisk Tidsskrift, v. 73, p. 109-132.

Stevens-Kalceff, M.A., 2009, Cathodoluminescence microcharacterization of point defects in $\alpha$-quartz: Mineralogical Magazine, v. 73, p. 585-606.

Stockmarr, P., 1994, A description of pegmatites at Åvesland and Evje, South Norway: Unpublished MSc thesis, University of Copenhagen, Denmark (in Danish).

Tanner, D., Henley, R.W., Mavrogenes, J.A., Holden P., 2013, Combining in situ isotopic, trace element and textural analyses of quartz from four magmatic-hydrothermal ore deposits: Contributions to Mineralogy and Petrology, v. 166, p. 1119-1142.

Thomas, J.B., Watson, B.E., Spear, F.S., Shemella, P.T., Nayak, S.K., and Lanzirotti, A., 2010, TitaniQ under pressure: the effect of pressure and temperature on the solubility of Ti in quartz. Contributions to Mineralogy and Petrology, v. 160, p. 743-759.

Touret, J.L., and Olsen, S.N., 1985, Fluid inclusions in migmatites, in Ashworth, J.R., ed., Migmatites, Glasgow, Blackie \& Son, p. 265-288.

Unimin Corporation, 2014, Iota product range. <http://www.iotaquartz.com/productrange.cfm> Accessed 2 May 2014.

Van den Kerkhof, A.M., and Hein, U.F., 2001, Fluid inclusion petrography: Lithos, v. 55, p. 27-47.

Van den Kerkhof, A. M., Kronz, A., Simon, K. and Scherer T., 2004, Fluid-controlled quartz recovery in granulite as revealed by cathodoluminescence and trace element analysis 
(Bamble sector, Norway): Contributions to Mineralogy and Petrology, v. 146, p. 637652.

Vander Auwera, J., Bolle, O., Bingen, B., Liégeois, J.-P., Bogaerts, M., Duchesne, J.C., De Waele, B., and Longhi, J., 2011, Sveconorwegian massif-type anorthosites and related granitoids result from post-collisional melting of a continental arc root: Earth-Science Reviews, v. 107, p. 375-397.

Wark, D.A. and Watson, E.B., 2006, TitaniQ: a titanium-in-quartz geothermometer: Contributions to Mineralogy and Petrology, v. 152, p. 743-754.

Wark, D.A., Hildreth, W., Spear, F.S., Cherniak, D.J. and Watson, E.B., 2007, Pre-eruption recharge of the Bishop magma system: Geology, v. 35, p. 235-238.

Watt, G.R., Wright, P., Galloway, S. and McLean, C., 1997, Cathodoluminescence and trace element zoning in quartz phenocrysts and xenocrysts: Geochimica et Cosmochimica Acta, v. 61, p. 4337-4348.

Weil, J.A., 1993, A review of the EPR spectroscopy of the point defects in a-quartz: the decade 1982-1992, in Helms, C.R. and Deal, B.E., eds, Physics and Chemistry of $\mathrm{SiO}_{2}$ and the Si-SiO interface 2, Plenum Press, New York, p. 131-144.

Westphal, M., Schumacher, J.C., and Boschert, S., 2003, High-temperature metamorphism and the role of magmatic heat sources at the Rogaland anorthosite complex in Southwestern Norway: Journal of Petrology, v. 44, p. 1145-1162.

Wiebe, R.A., Wark D.A. and Hawkins D.P., 2007, Insights from quartz cathodoluminescence zoning into crystallization of the Vinalhaven granite, coastal Maine: Contributions to Mineralogy and Petrology, v. 154, p. 439-453.

Wilmart, E., and Duchesne, J.C., 1987, Geothermobarometry of igneous and metamorphic rocks around the Ana-Sira anorthosite massif: implications for the depth of emplacement of the South Norwegian anorthosites: Norsk Geologisk Tidsskrift, v. 67, p. 185-196. 


\section{Appendices (available via online version of the paper)}

Table A1. Trace element concentrations in quartz from pegmatites of the Evje-Iveland and Froland pegmatite fields in south Norway. Concentrations were determined by LA-ICP-MS. LOD - limit of detection, n.d. - not determined.

Table A2. Total race element concentrations of quartz and quartz tonnage (deposit size) of Evje-Iveland and Froland pegmatites in south Norway. The total trace element contents, determined by LA-ICP-MS, were calculated by summing up the average concentrations of all measured elements. The half of the detection limit amount was considered for concentrations which were below the detection limit (see Table A1). The tonnages were calculated by using the pegmatite size multiplied by the density of $2.65 \mathrm{t} \mathrm{m}-3$ and quartz portion of 0.2 in the pegmatites. n.d. - not determined. 


\section{Figures}

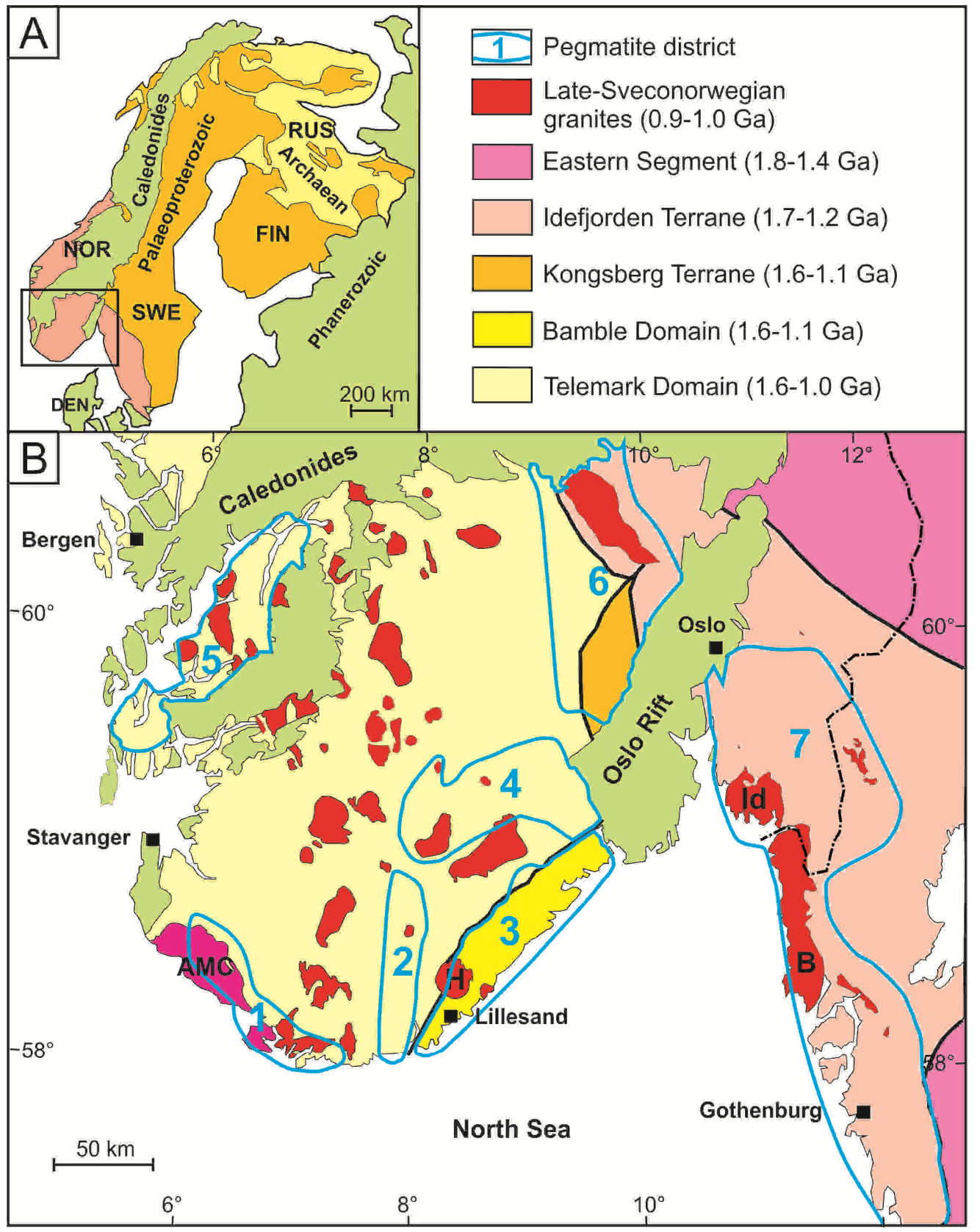

Fig. 1. The Sveconorwegian pegmatite province. A - Schematic map of Fennoscandia with the extension of the Sveconorwegian orogeny (pinkish areas). B - Simplified geological map of southern Norway and parts of southwestern Sweden showing the locations of pegmatite districts within the Sveconorwegian pegmatite province (areas framed with solid blue lines): 1 - Mandal, 2 - Setesdal, 3 - Bamble, 4 - Nissedal, 5 - Hardanger, 6, Buskerud, 7 - ØstfoldHalland. AMC - Rogaland anorthosite-mangerite-charnockite complex, B - Bohus granite, H - Herefoss granite, Id - Idefjord granite. 


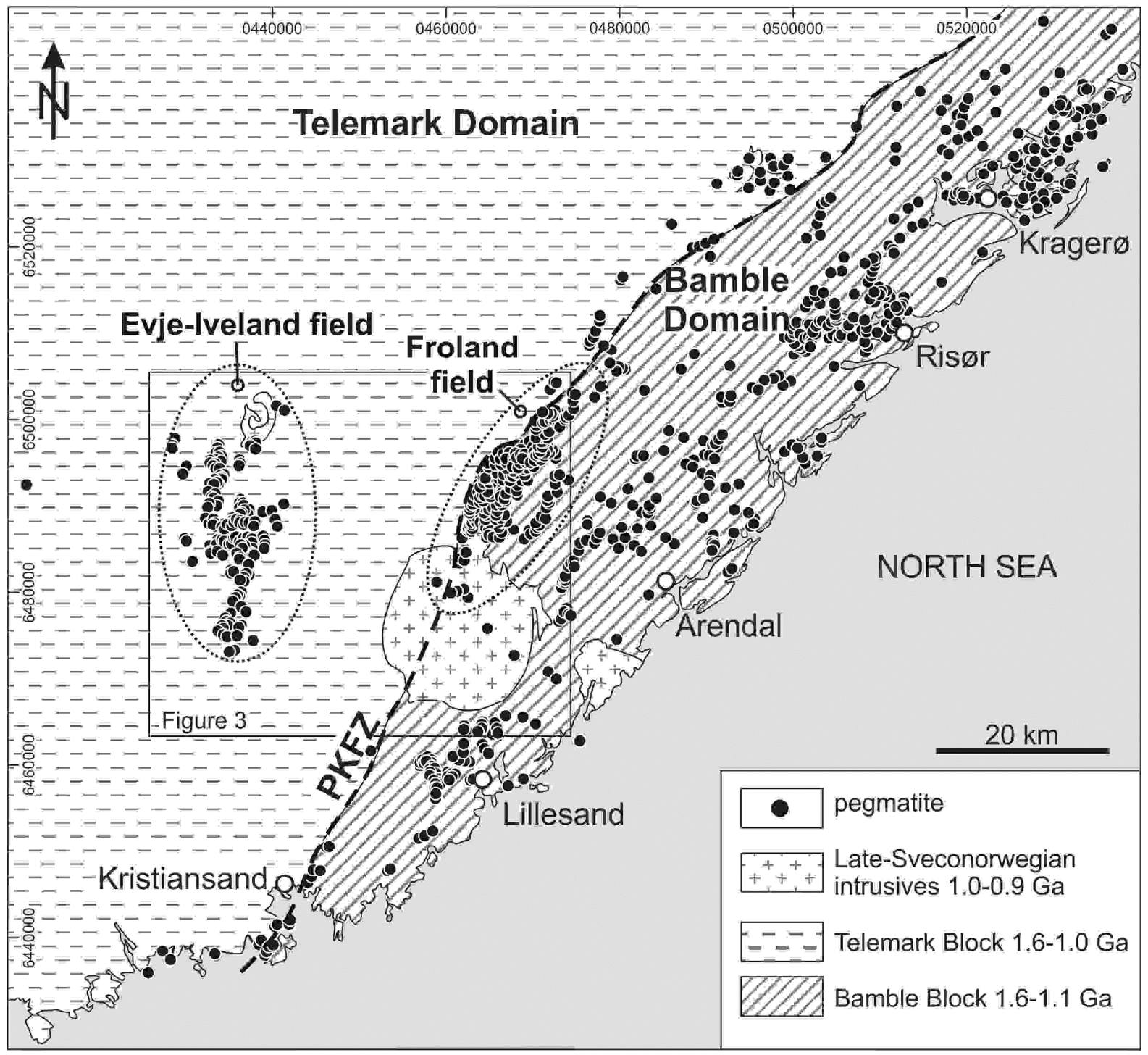

Fig. 2. Simplified geological map showing the distribution of pegmatites in the Bamble and Setesdalen pegmatite districts and the location of the Evje-Iveland and Froland pegmatite fields within these districts. PKFZ - Porsgrunn-Kristiansand Fault Zone. 


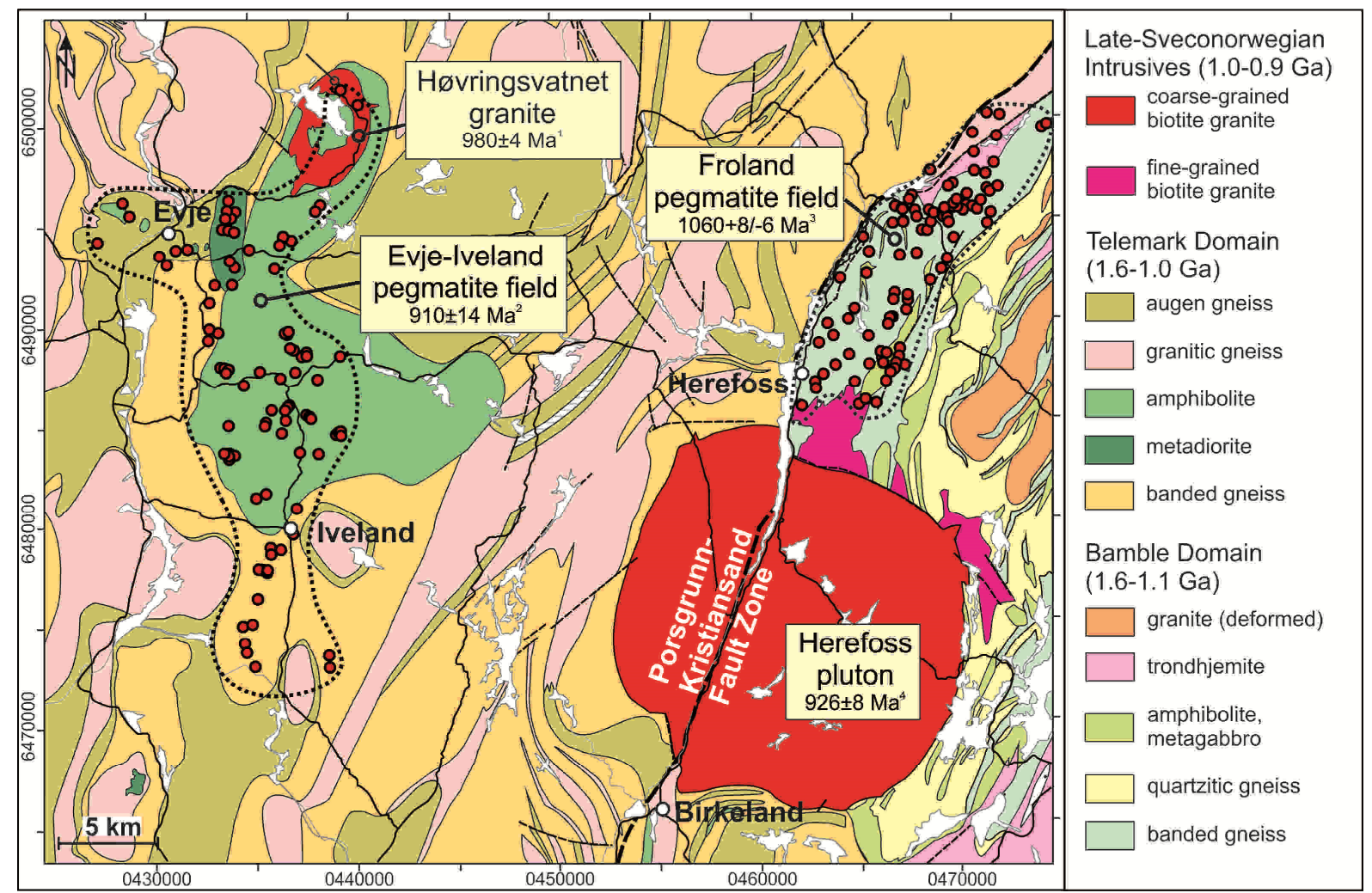

Fig. 3. Simplified geological map with the location of the investigated pegmatite fields of Froland and Evje-Iveland. References of emplacement ages: 1 - Snook (2014); 2 - Scherer et al. (2001); 3 - Baadsgaard et al. (1984); 4 - Andersen (1997). 


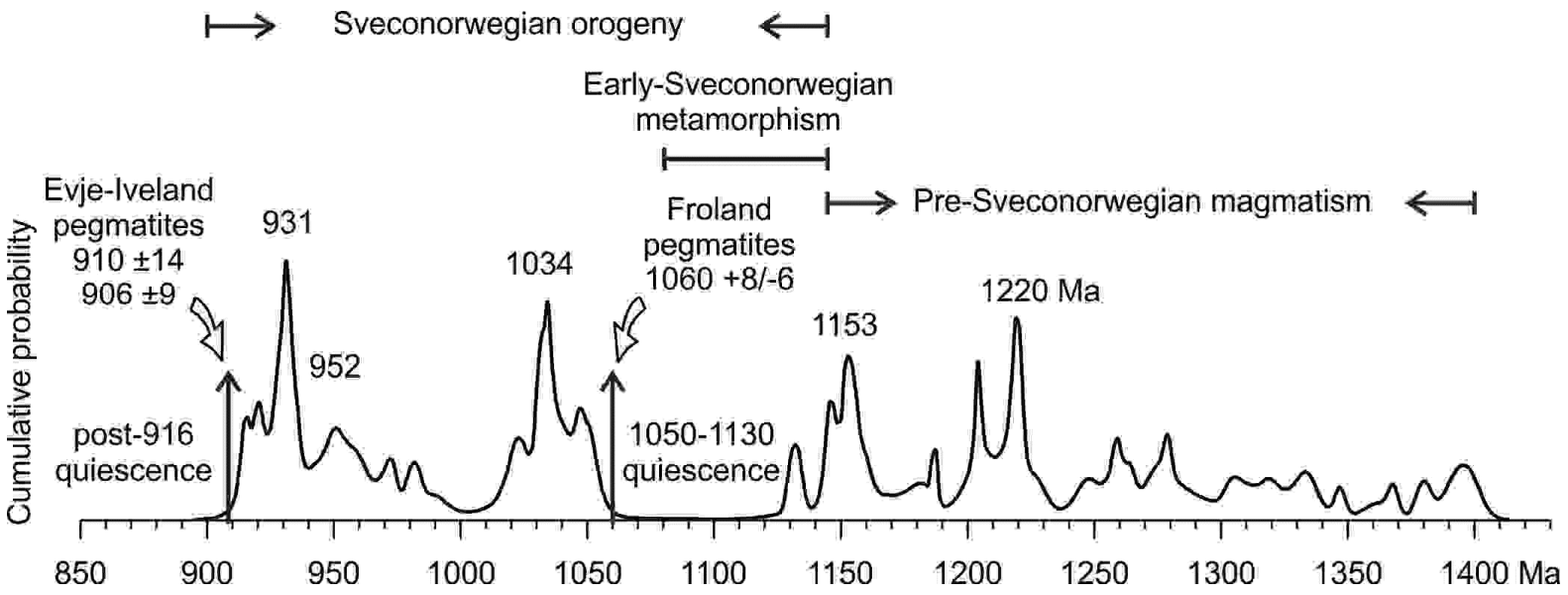

Fig. 4. Cumulative probability curve for U-Pb geochronological data on 171 magmatic rocks younger than $1400 \mathrm{Ma}$, distributed over the whole Sveconorwegian orogen, following the database of Bingen et al. (2011; updated at the end of 2014). The cumulative probability curve include plutonic and volcanic rocks, but excludes pegmatites. The age of the EvjeIveland and Froland pegmatites are from Scherer et al. (2001), Seydoux-Guillaume et al. (2012) and Baadsgaard et al. (1984). The figure shows that both the Froland pegmatites and the Evje-Iveland pegmatites intruded during a period of magmatic quiescence at the scale of the orogen. This argues against a derivation of the pegmatite melts from hypothetic parental granite plutons that would be concealed. 

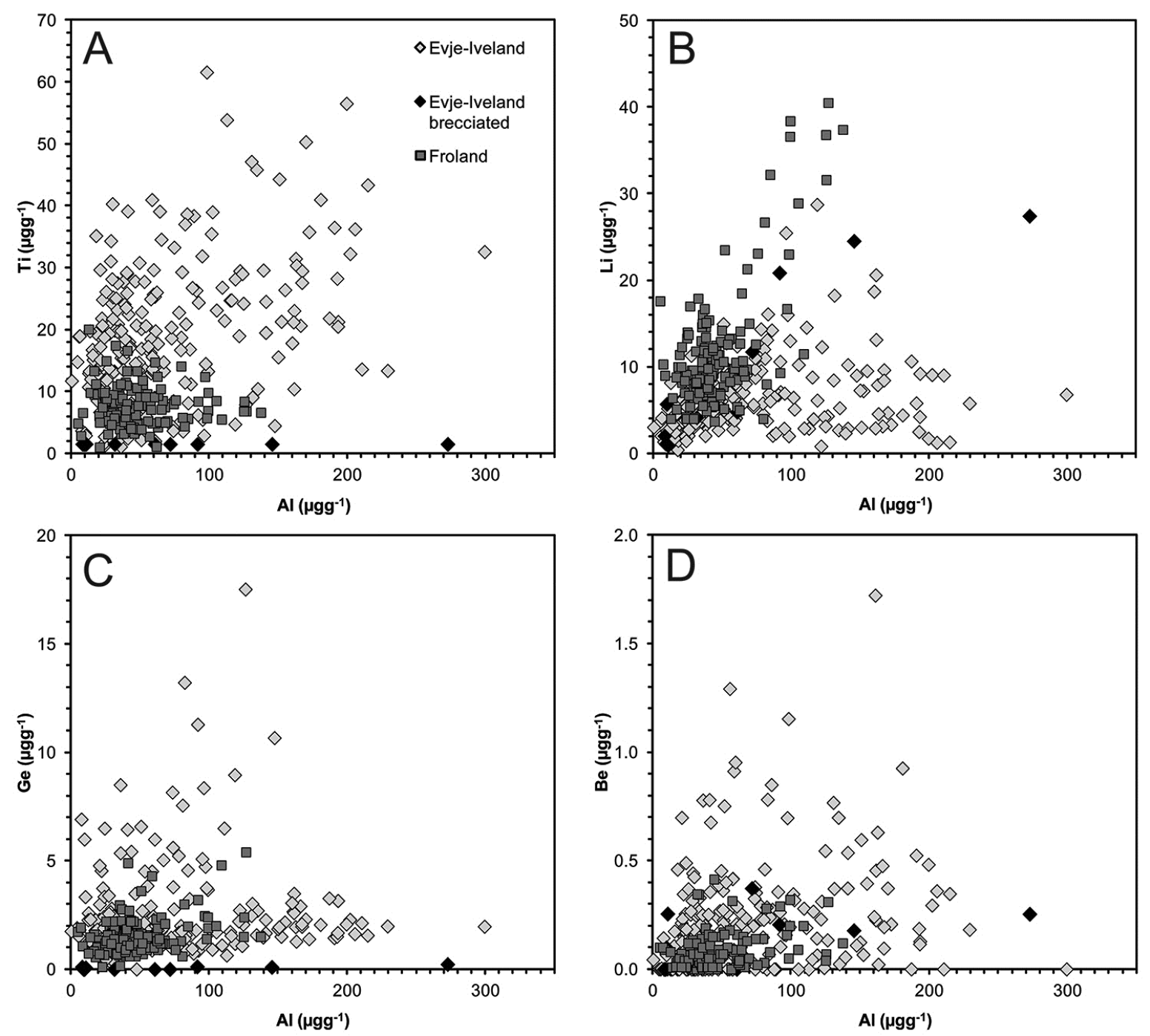

Fig. 5. Variation diagrams for trace elements in pegmatite quartz from Froland and EvjeIveland determined by LA-ICP-MS. Detection limits are $5.0 \mu \mathrm{gg}^{-1}$ for $\mathrm{Al}, 1.5 \mu \mathrm{gg}^{-1}$ for Ti, $0.5 \mu \mathrm{gg}^{-1}$ for $\mathrm{Li}, 0.20 \mu \mathrm{gg}^{-1}$ for $\mathrm{Ge}$ and $0.15 \mu \mathrm{gg}^{-1}$ for Be. Quartz from the brecciated pegmatites at Landsverk is shown as different symbols because it does not represent igneous quartz crystallised from pegmatite melts. 

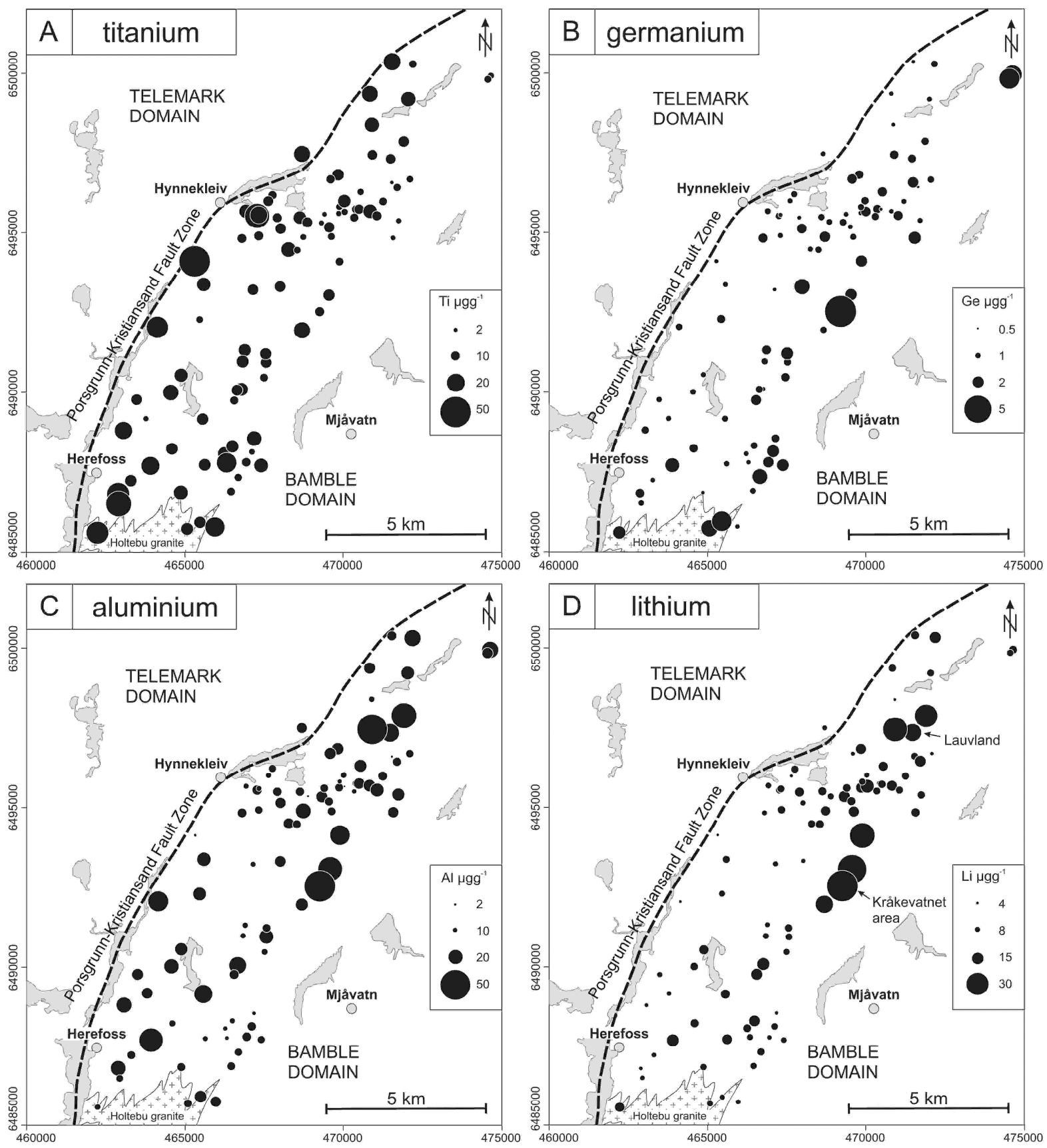

Fig. 6. Regional distribution of $\mathrm{Ti}$ and $\mathrm{Li}$ concentrations in quartz from the Froland pegmatite field. The diameter of the filled circles increases with element concentration in the quartz. Concentration ranges are 2.2 to $20.1 \mu \mathrm{gg}^{-1}$ for Ti and 4.0 to $40.5 \mu \mathrm{gg}^{-1}$ for $\mathrm{Li}$. 

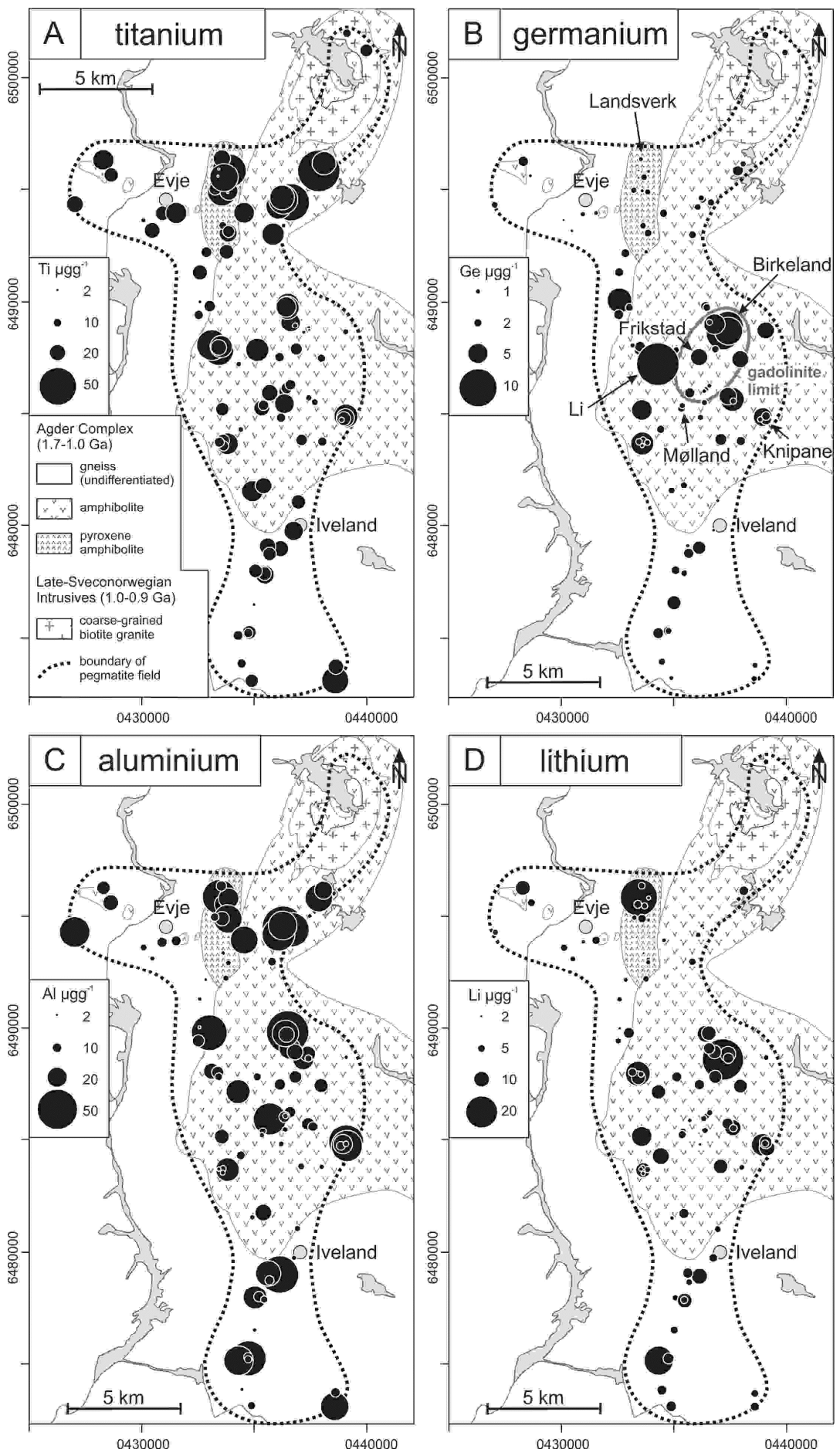

Fig. 7. Regional distribution of $\mathrm{Ti}$ and $\mathrm{Li}$ concentrations in quartz from the Evje-Iveland pegmatite field. The diameter of the filled circles increases with element concentration in the quartz. Concentration ranges are 2.2 to $20.1 \mu \mathrm{gg}^{-1}$ for Ti and 4.0 to $40.5 \mu \mathrm{gg}^{-1}$ for $\mathrm{Li}$. 


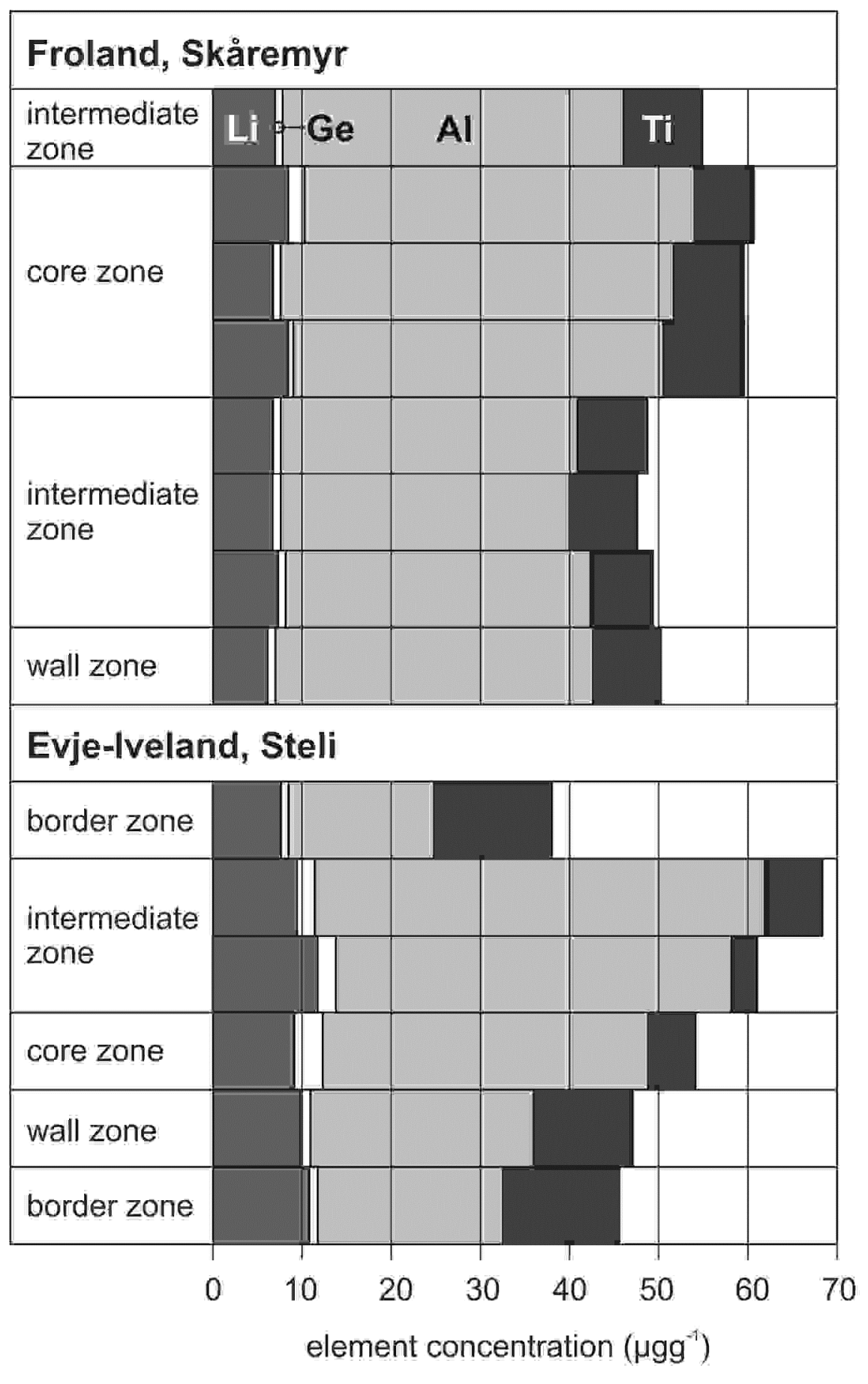

Fig. 8. Bar charts illustrating variations in $\mathrm{Li}, \mathrm{Ge}, \mathrm{Al}$, and Ti contents of quartz from different zones across pegmatite bodies. Each bar represent the average of two (Skåremyr pegmatite) or three (Steli pegmatite) LA-ICP-MS analyses. 


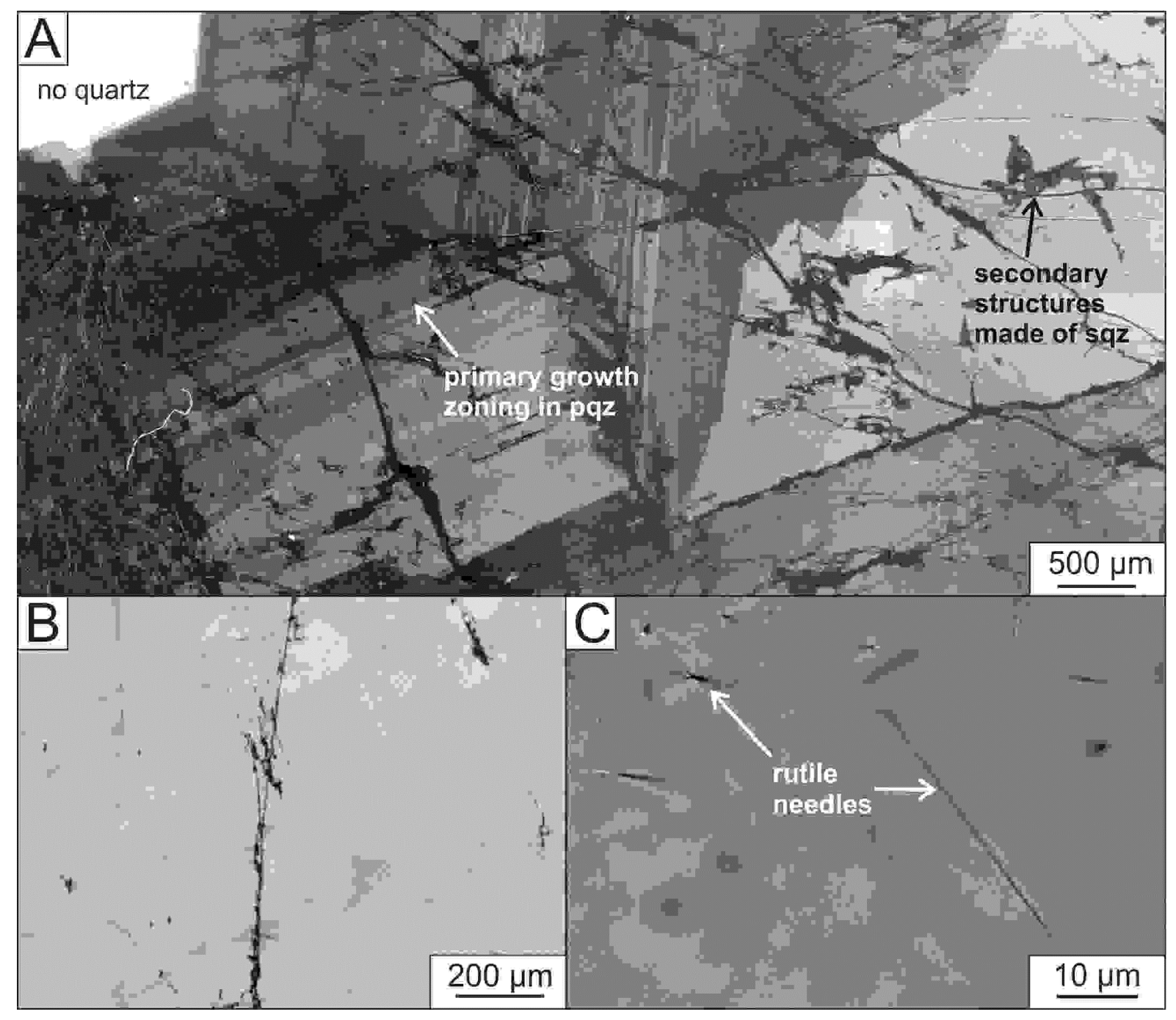

Fig. 9. A - SEM-CL image of the base of a $12 \mathrm{~cm}$ long, euhedral pocket quartz from a replacement zone of the Birkeland 3 pegmatite crystallized at c. $450^{\circ} \mathrm{C}$ (Müller, unpublished data). The well preserved (sharp) growth zoning in primary quartz (pqz) indicates low diffusion distances of $\mathrm{Ti}$ after crystallization because $\mathrm{Ti}$ is mainly responsible for the CLvisualized growth zoning in igneous quartz. A network of micro fractures healed with secondary, dull to non-luminescent quartz (black; sqz) overprinted partially primary features. B - SEM-CL image of homogeneous pegmatite quartz from the intermediate zone of the Birkeland 3 pegmatite showing no primary zoning at thin section scale but several thin fractures healed with secondary quartz (black). C - Optical microscopy image (plane light) of submicroscopic rutile needles in pegmatite quartz from the Birkeland 3 pegmatite. 


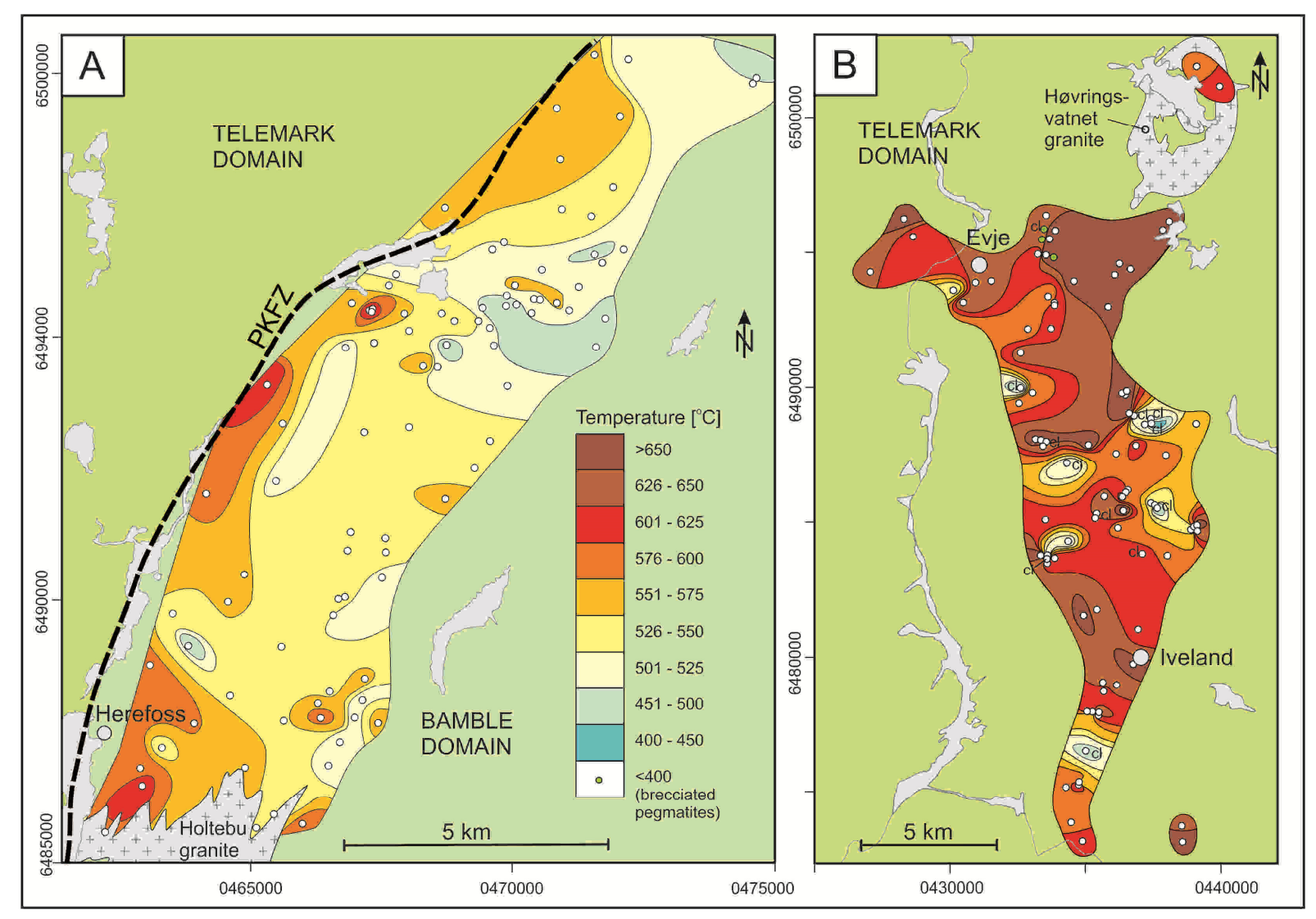

Fig. 10. Isotherm maps of the crystallization temperatures of pegmatite quartz from the Froland (A) and Evje-Iveland (B) fields. The temperature was calculated from average Ti concentration (2 to 3 LA-ICP-MS analyses) of quartz from the intermediate zone of the pegmatites applying the Ti-in-quartz geothermobarometry (Huang and Audétat, 2012). The uncertainty in the crystallization pressure leads to an error of $\pm 10^{\circ} \mathrm{C}$ in the temperature for the Froland quartz and $\pm 11^{\circ} \mathrm{C}$ for the Evje-Iveland quartz. Crystallization temperatures of hydrothermal quartz from the brecciated pegmatites from Landsverk (green dots) were excluded when generating the isotherms. cl - pegmatites with "amazonite"-cleavelandite" replacement zones. 


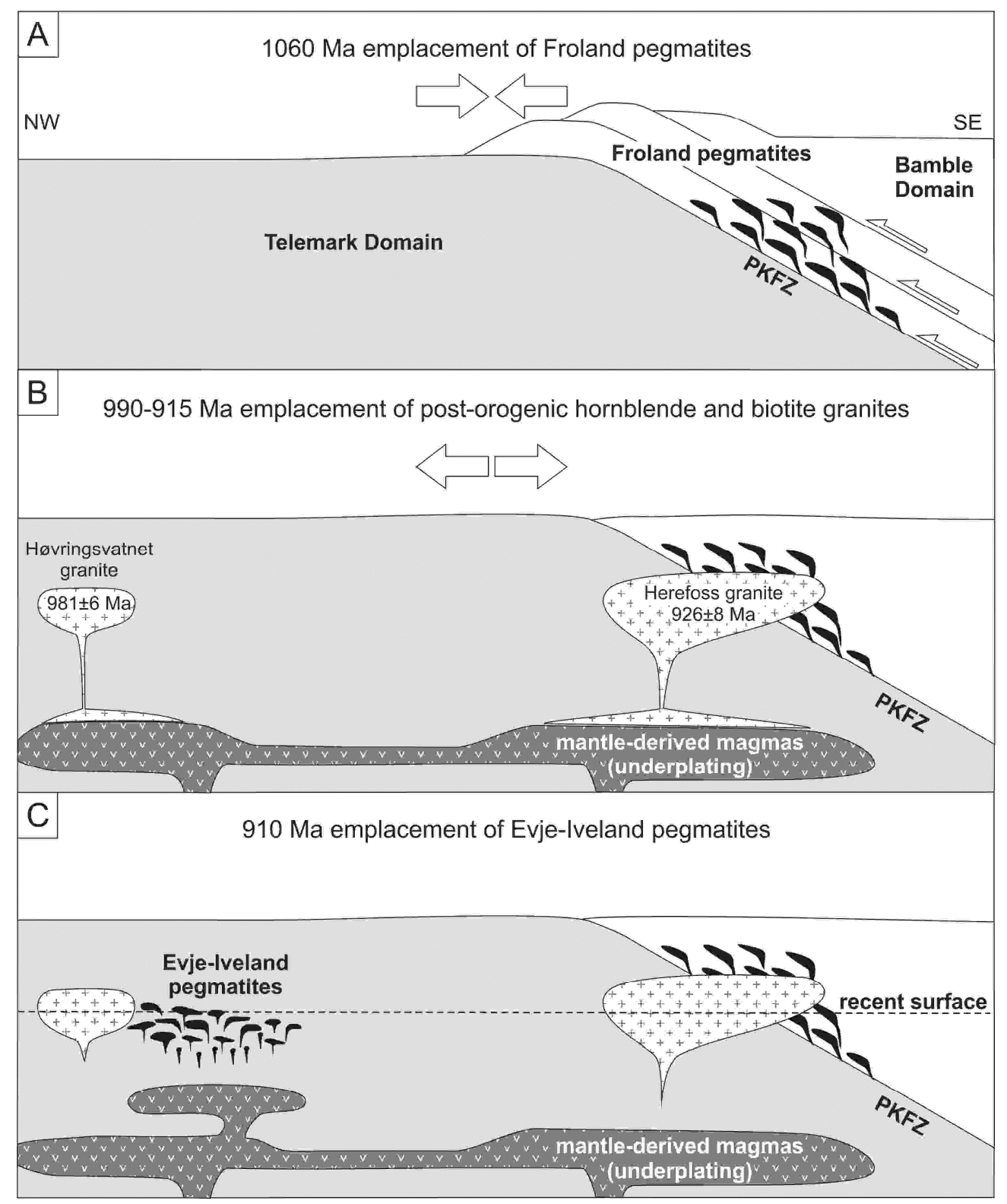

Fig. 11. Schematic NW-SE section of the Sveconorwegian orogeny illustrating its late stages of tectono-magmatic evolution. A - Generation and emplacement of the Froland pegmatite melts during increasing compressive deformation along the Kristiansand-Porsgrunn fault/thrust zone (PKFZ) at about 1060 Ma. B - Emplacement of the post-orogenic granites of Høvringsvatnet and Herefoss during the dilatation and relaxation of the Sveconorwegian orogeny. $\mathrm{C}$ - Generation and emplacement of the Evje-Iveland pegmatite melts by partial melting of amphibolites during a low pressure/high-temperature event. 

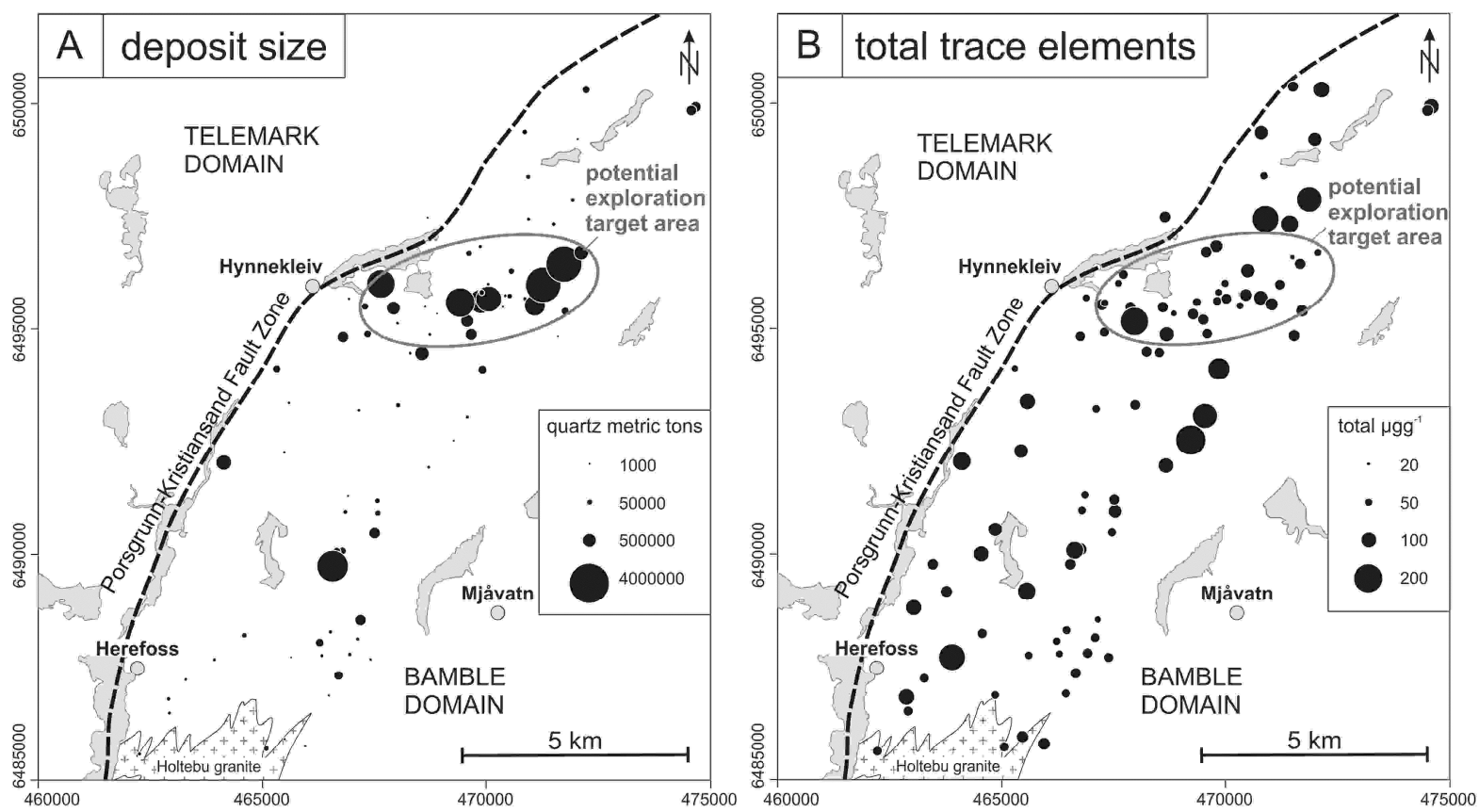

Fig. 12. Maps showing the regional distribution of (A) quartz resources (deposit size) applying a quartz content of $20 \mathrm{wt} . \%$ in the pegmatites and (B) the total trace element contents in quartz from the Froland pegmatites. The total contents were calculated by summing up the concentrations of all measured elements. The half of the detection limit amount was considered for element concentrations which were below the detection limit. The grey ellipse frames the area with the highest potential for economic deposits. 


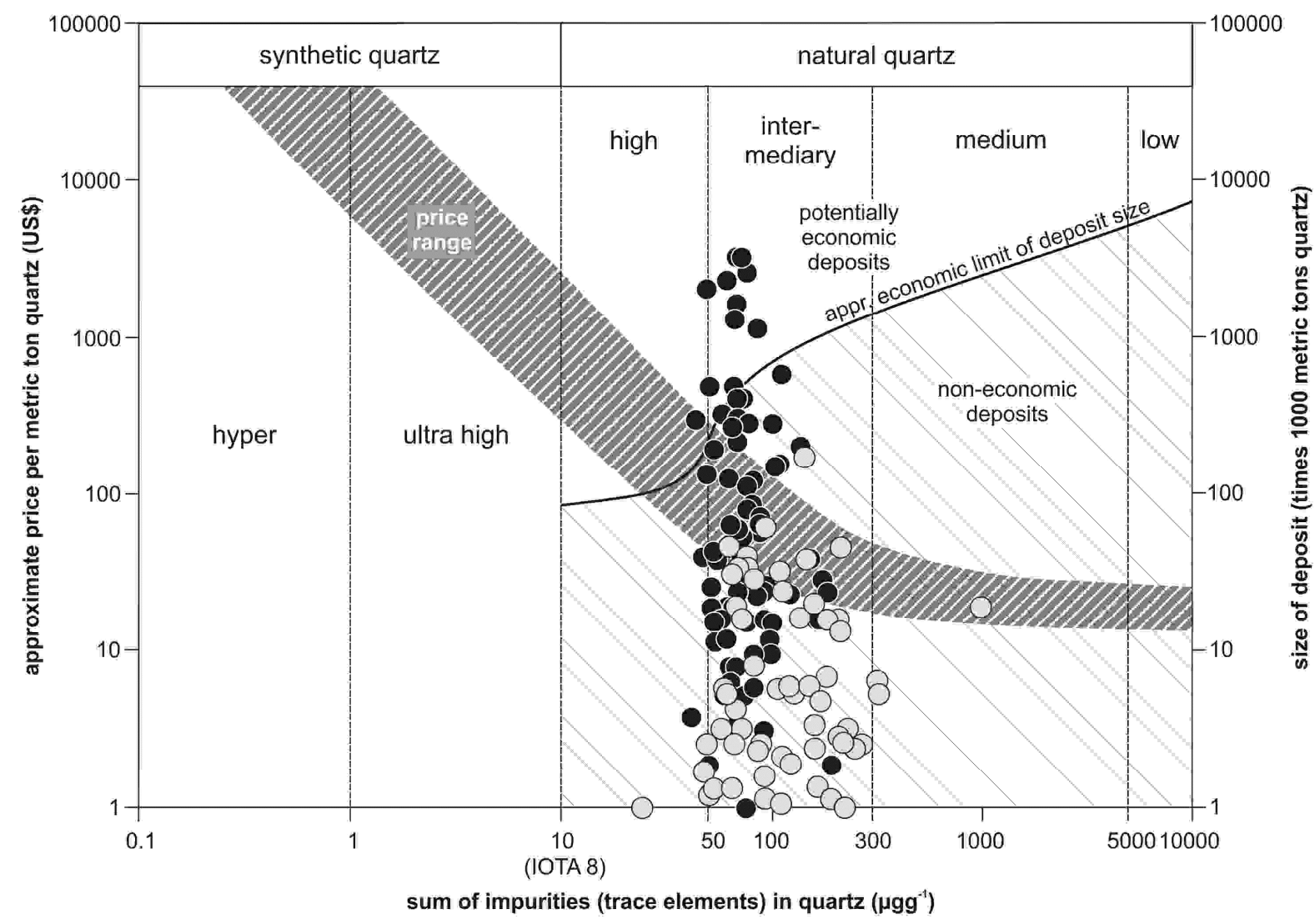

Fig. 13. Graph illustrating the economic potential of quartz deposits integrating the chemical quality of quartz, expressed as total trace element content, and deposit size, according to Müller et al. (2012b, slightly modified). The tonnages were calculated by using the pegmatite size multiplied by the density of $2.65 \mathrm{t} \mathrm{m}^{-3}$ and quartz portion of 0.2 in the pegmatites. The total trace element contents were calculated by summing up the average concentrations of all measured elements (Table A2). The half of the detection limit amount was considered for concentrations which were below the detection limit. The boundaries between different quartz qualities are from Harben et al. (2002). The best quality produced from natural quartz

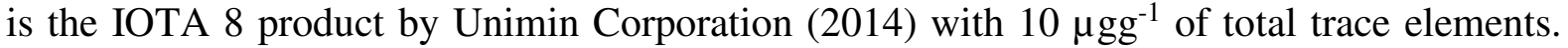
Quartz with lower trace element concentrations can be produced synthetically only. Froland pegmatites are shown in black dots and the Evje-Iveland pegmatites in grey dots. The grey shaded area indicates the approximate price range of the different quartz qualities. 

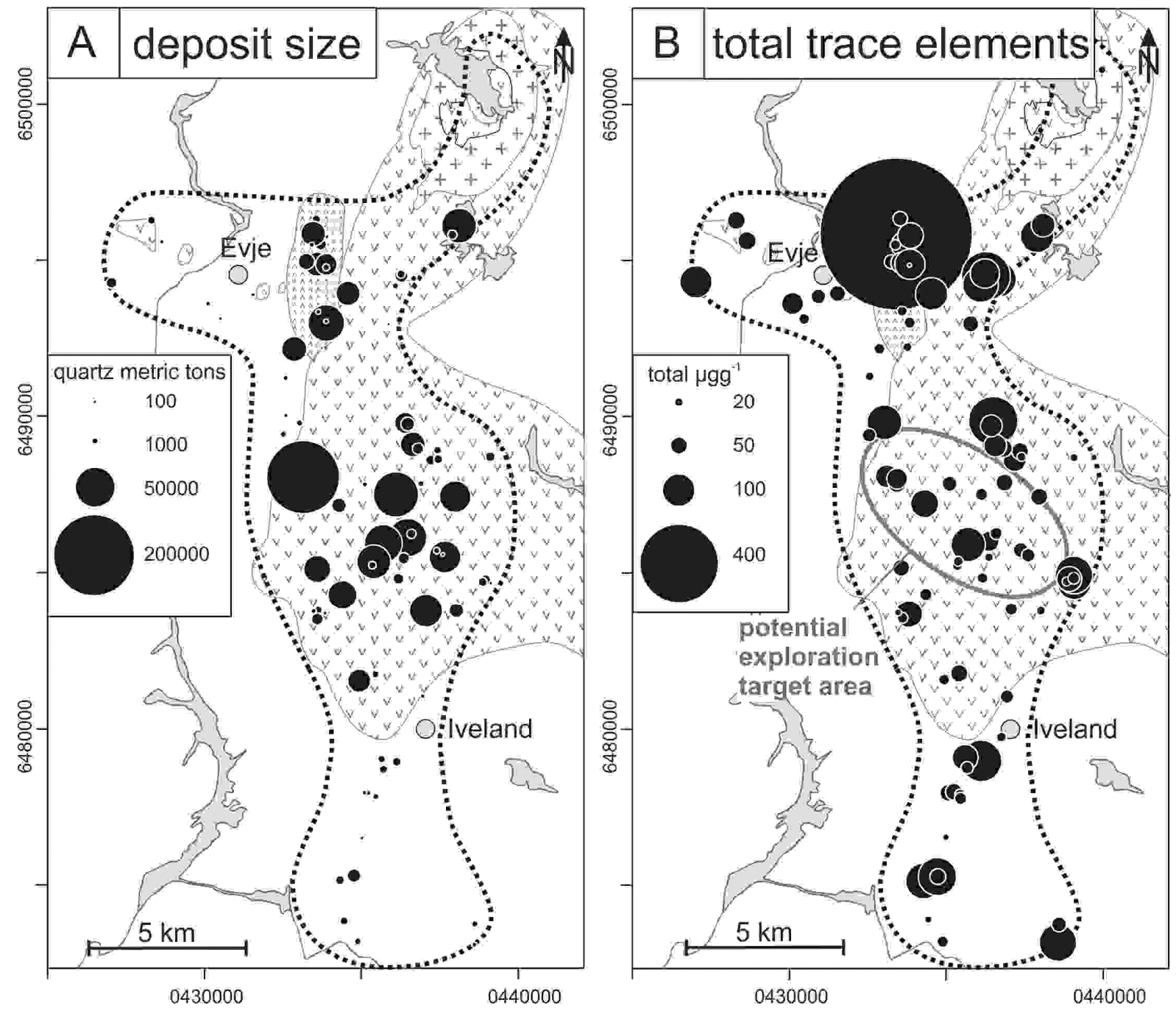

Fig. 14. Maps showing the regional distribution of (A) quartz resources (deposit size) applying a quartz content of $20 \mathrm{wt} . \%$ in the pegmatites and (B) the total trace element contents in quartz from the Evje-Iveland pegmatites. The total contents were calculated by summing up the concentrations of all measured elements. The half of the detection limit amount was considered for element concentrations which were below the detection limit. The grey ellipse frames the exploration target area which has the highest potential for economic deposits. 